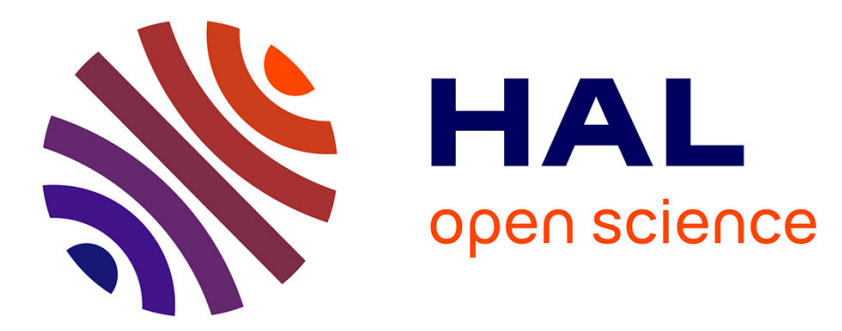

\title{
New archeointensity data from Novgorod (North-Western Russia) between c. 1100 and 1700 AD. Implications for the European intensity secular variation
} Natalia Salnaia, Yves Gallet, Agnès Genevey, Ilya Antipov

\section{- To cite this version:}

Natalia Salnaia, Yves Gallet, Agnès Genevey, Ilya Antipov. New archeointensity data from Novgorod (North-Western Russia) between c. 1100 and 1700 AD. Implications for the European intensity secular variation. Physics of the Earth and Planetary Interiors, 2017, 269, pp.18 - 28. 10.1016/j.pepi.2017.05.012 . hal-01529266

\section{HAL Id: hal-01529266 \\ https: / hal.sorbonne-universite.fr/hal-01529266}

Submitted on 30 May 2017

HAL is a multi-disciplinary open access archive for the deposit and dissemination of scientific research documents, whether they are published or not. The documents may come from teaching and research institutions in France or abroad, or from public or private research centers.
L'archive ouverte pluridisciplinaire HAL, est destinée au dépôt et à la diffusion de documents scientifiques de niveau recherche, publiés ou non, émanant des établissements d'enseignement et de recherche français ou étrangers, des laboratoires publics ou privés. 
1 New archeointensity data from Novgorod (North-Western Russia) between c. 1100 and

21700 AD. Implications for the European intensity secular variation

3 Natalia Salnaia ${ }^{1}$, Yves Gallet $^{2}$, Agnès Genevey $^{3}$, Ilya Antipov ${ }^{4}$

4

$5{ }^{1}$ Institute of Physics of the Earth, Russian Academy of Sciences, Moscow, Russia, 6 natasavi@inbox.ru, corresponding author

$7 \quad{ }^{2}$ Institut de Physique du Globe de Paris- Sorbonne Paris Cité- Université Paris Diderot, UMR 87154 CNRS, Paris, France

$9 \quad{ }^{3}$ Sorbonne Universités, UPMC Univ. Paris 6, CNRS, UMR 8220, Laboratoire d'archéologie 10 moléculaire et structurale (LAMS), Paris, France

$11{ }^{4}$ Institute of History, St Petersburg State University, St Petersburg, Russia

Abstract millennium is challenging because of the lack of recently acquired archeomagnetic data from Western Russia. In this paper, we report on nine new archeointensity values obtained from groups of brick fragments sampled in Novgorod (North-Western Russia) and its vicinities. These fragments were collected from churches whose precise ages range from the beginning of the 12th century to the end of the 17th century AD. All the archeointensity measurements were carried out using the Triaxe experimental protocol, which takes into account the thermoremanent magnetization (TRM) anisotropy effect. Intensity determinations were performed using fast and slow cooling rates for laboratory-TRM acquisition. The results confirm that the Triaxe protocol overcomes the TRM cooling rate dependence. The new data

24 shows that geomagnetic field intensities in North-Western Russia have decreased in the past millennium. Comparisons were made with other data previously obtained in Western Europe, 
the Balkans and Russia, as well as with intensity values expected in Novgorod from global geomagnetic field models. These comparisons yielded three main results: 1) The new archeointensity data do not show the occurrence of large intensity variations in NorthWestern Russia, as those observed in the Balkan dataset. Conversely, they appear more compatible with Western European results, which suggests a limited non-dipole field effect across Europe during the past millennium; 2) Our data are weaker than the intensity values expected in Novgorod from the available global geomagnetic field models. This suggests that the field models are inaccurate for the Novgorod area; 3) A constant linear decrease of the geocentric axial dipole moment since 1600 AD does not appear compatible with our younger data.

Keywords: Secular variation, geomagnetic field intensity, past millennium, North-Western Russia, Europe, geomagnetic field modeling.

\section{Introduction}

For the past 15 years, considerable efforts have been made to improve our knowledge of the secular variation in Western Eurasia's geomagnetic field over the past few millennia. In

Western Europe, these efforts were focused on the recovery of both the directional (e.g. Gallet et al., 2002; Hervé et al., 2013a) and field intensity variations for the period spanning the past two to three millennia, with significant progress (e.g. Gómez-Paccard et al., 2008; 2012; 2016; Gallet et al., 2009; Genevey et al., 2009; 2013; 2016; Hervé et al., 2013b; 2016). The overall geomagnetic field intensity variation curve in Western Europe, which covers the past three millennia, is now one of the best documented and detailed curve 
51 insufficient number of data as is, for instance, the case for the first millennium BC (Hervé et 52 al., 2013b; 2016). In contrast, the past 1500 years are particularly well documented, revealing a geomagnetic signal punctuated by a series of centennial-scale intensity peaks (Genevey et al., 2013; 2016). This well-defined curve demonstrates that recovering the intensity secular variation at the centennial time scale is a difficult but achievable target.

At present, only the important dataset obtained in the Balkans (South-Eastern Europe) including results from Bulgaria (Kovacheva et al., 2014), Greece (e.g. Tema and Kondopoulou, 2011; Tema et al., 2012) and Southern Italy (e.g. Tema et al., 2013) can be used to carry out a comparison between the geomagnetic intensity variations that occurred in Western and Eastern Europe (e.g. Genevey et al., 2013, 2016; Pavón-Carrasco et al., 2014a). The Balkan data appear rather dispersed. They exhibit large intensity fluctuations with trends like those observed in Western Europe, though with higher amplitude. The resolution of this curve, however, does not have enough detail to conclude on the occurrence of drifting nondipole sources, westward nor eastward, between Western and Eastern Europe during the past 1500 years (Genevey et al., 2016). Given the available data, Pavón-Carrasco et al. (2014a) concluded that the geomagnetic field intensity evolution over the past few millennia was likely homogeneous across Europe.

In other sub-regions of Europe, archeointensity data are still not numerous enough to further constrain the issue of homogeneity in intensity variations over this semi-continental wide area. This is the case for North-Western Russia, around the city of Novgorod $\left(\lambda=58.52^{\circ} \mathrm{N}, \phi=31.27^{\circ} \mathrm{E}\right)$. Here archeointensity data dated to the Medieval period and meeting minimum quality criteria are virtually absent (e.g. Burlatskaya et al., 1986; Genevey et al., 2008; Pavón-Carrasco et al., 2014a). During the first half of the second millennium AD, this

74 region was economically rich because of active trading with other Russian lands and the 
that time using baked-clay bricks, which makes this region a promising target for an archeomagnetic study. New archeointensity results from this region could further be used to test (and later to improve) the reliability of the available global archeomagnetic field models (e.g. Licht et al., 2013; Pavón-Carrasco et al., 2014b; Nilsson et al., 2014.). In this paper, we report on new archeointensity data obtained from the Novgorod area, dated between c. 1100 $\mathrm{AD}$ and c. $1700 \mathrm{AD}$.

\section{Archeomagnetic sampling}

All archeological fragments analyzed in this study consist of baked clay bricks collected from churches located in Novgorod (North-Western Russia) and its surroundings (Fig. 1). The oldest reference to the city of Novgorod goes back to the middle of the 9th century $\mathrm{AD}$, making it one the most ancient Russian cities. During the 10th century AD, Novgorod was already a prosperous city because of its position on the trading route from the Varangians (i.e. the other name of Vikings) to the Greeks. Between the 11th and the 15th centuries, Novgorod was the capital city of the Novgorodian Republic, which extended from the Baltic to Northern Urals. This republic ended in 1478 AD when its territory became annexed to the state of Muscovy under the reign of Ivan III. During the republic period, many churches were built in the city of Novgorod and in nearby monasteries using bricks, local stones, or a combination of both. The construction date of these churches is known within a 17-yr uncertainty thanks to historical sources such as the Novgorod first chronicle (Fig. 2, Table 1; Nasonov, 1950; English translation in Michell and Forbes, 1914).

It is important to emphasize that the bricks used for construction are of local origin. The craftsmen benefited from abundant clay sources near Novgorod, which allowed the development of important pottery production activity, likely accompanied by brick manufacturing (e.g. Antipov and Gervais, 2015). The local origin of the bricks is also verified 
101 through the discovery of a kiln at Ryurik Gorodishche, an area approximately $2 \mathrm{~km}$ south of 102 the Novgorod center (Gervais and Lipatov 2003; Lipatov, 2005), whose brick production 103 activity served to build the church of the Annunciation in the Gorodishche (site BGA01; Fig. 104 2a, Table 1) in 1103 AD. Recently, the continuous activity of brick production in Novgorod 105 with a regional distribution was further substantiated by the discovery of a ship carrying a 106 load of bricks that sunk to the bottom of the Volkhov river (Antipov and Gervais, 2015). 107 Interestingly, no evidence for an active brick market in Novgorod during the Middle Ages 108 was found in the archives, nor for a large storage space for the fabricated bricks within the city. This indicates that the time delay between the production and the use of the bricks was 110 most probably very short and the bricks were likely fired on request for specific buildings.

The archeomagnetic sampling of bricks was performed either on still standing 112 churches or on vestiges found during excavations (Fig. 3). We note that the typology 113 evolution of the bricks (see description and discussion in Antipov and Gervais, 2015) 114 provided us with an additional guide for only selecting the bricks used in the original phase of 115 the buildings, thus avoiding the bricks used in possible late renovations, or for identifying the 116 bricks from different construction phases. Here we present new archeointensity data obtained 117 from nine groups of brick fragments sampled from the remains of different churches. The 118 bricks were dated from the beginning of the 12 th century to the end of the 17 th century AD 119 (Table 1). The age distribution is inhomogeneous: four groups for the 12th and three for the 120 14th centuries. The absence of fragments from the 13th century is linked to the Mongol 121 invasion of 1238-1240 AD. Although the invasion did not destroy the city of Novgorod, it 122 caused a marked slowdown in regional economic activity and thus led to a limited number of 123 new constructions during most of this century. 


\section{Acquisition of new archeointensity data}

127

\subsection{Methods}

Archeointensity data were obtained using the experimental protocol developed for the Triaxe magnetometer (Le Goff and Gallet, 2004). The Triaxe is a vibrating sample magnetometer that allows continuous high-temperature (up to $670^{\circ} \mathrm{C}$ ) magnetization measurements of a small $\left(<1 \mathrm{~cm}^{3}\right)$ cylindrical sample. It further allows the acquisition of a thermoremanent magnetization (TRM) in any direction and in a field intensity up to $200 \mu \mathrm{T}$. Le Goff and Gallet (2004) designed an automated routine for intensity determinations that involves a succession of five series of measurements performed between two temperatures referred to as $\mathrm{T} 1$ and $\mathrm{T} 2$. $\mathrm{T} 1$ is generally set to $150^{\circ} \mathrm{C}$ and $\mathrm{T} 2$, in the present study, was chosen between $440^{\circ} \mathrm{C}$ and $520^{\circ} \mathrm{C}$ depending on the specimens (see below). The NRM of the specimen is first demagnetized up to T2 (first series of measurements), while the thermal variations between $\mathrm{T} 1$ and $\mathrm{T} 2$ of the magnetization fraction still blocked above $\mathrm{T} 2$ are recorded twice during the second (between $\mathrm{T} 2$ and $\mathrm{T} 1$ ) and third series of measurements (between T1 and T2). A laboratory TRM is then acquired between T2 and T1 (fourth series of measurements), which is demagnetized up to T2 during the fifth series of measurements. The protocol ends with the cooling of the specimen down to room temperature. Intensity determinations are derived from the magnetization data acquired every $5^{\circ} \mathrm{C}$ during the first, third and fifth series of measurements, i.e. in the very same heating conditions between T1 and T2. These measurements can be expressed through two ratios, which are multiplied by the field intensity used for laboratory-TRM acquisition, and defined as R(Ti) and R'(Ti) in Le Goff and Gallet (2004). R(Ti) is the ratio between the NRM and TRM fractions with unblocking temperatures between the running temperature $\mathrm{Ti}$ and $\mathrm{T} 2$, whereas $\mathrm{R}$ '(Ti) is the ratio between the NRM and TRM fractions unblocked between T1 and Ti. Le Goff and Gallet (2004) experimentally showed that $\mathrm{R}(\mathrm{Ti})$ is more prone to cooling rate effect over TRM 
151 acquisition at higher temperatures than $\mathrm{R}^{\prime}(\mathrm{Ti})$. For this reason, the mean intensity values are 152 derived at the specimen level from R'(Ti) data.

A great asset of the Triaxe protocol is that it avoids a correction for the TRM anisotropy effect because the laboratory TRM is acquired so that its direction is parallel to that of the NRM. A description of the procedure is provided in Le Goff and Gallet (2004) (see also in Genevey et al., 2008 for a general discussion on the TRM anisotropy effect). Thanks to numerous comparative tests with data obtained using more classical intensity techniques 158 (Thellier-Aitken/-Coe/-IZZI methods; Thellier and Thellier, 1959; Aitken et al., 1988; Coe, 1967; Yu et al., 2004) implying magnetization measurements at ambient temperature, it was also experimentally observed that the R'(Ti) intensity determinations account for the cooling 161 rate effect on TRM acquisition (Le Goff and Gallet, 2004; Gallet and Le Goff, 2006; Genevey et al., 2009; Hartmann et al., 2010; 2011 and see in Section 3c below). Furthermore, any bias in the intensity data possibly induced by the presence of multi-domain grains in the specimen is mitigated because the laboratory TRM is acquired under similar conditions as those of the NRM.

In the present study, the reliability of the Triaxe data relies on the same set of selection

167 criteria used by Genevey et al. $(2013 ; 2016)$ and Hartmann et al. $(2010 ; 2011)$. These criteria 168 aim to insure the nominal paleomagnetic behavior described in Le Goff and Gallet (2004), 169 which is characterized, in particular, by a "primary" univectorial magnetization component 170 isolated between $\mathrm{T} 1$ and $\mathrm{T} 2$, with the possibility to adjust a posteriori $\mathrm{T} 1$ to a higher 171 temperature (referred to $\mathrm{T} 1^{\prime}$ ') in case of a secondary magnetization component, and by rather 172 constant $\mathrm{R}$ '(Ti) data over this temperature range (i.e. with an overall slope "S" of less than 173 10\%). Rock magnetic analyses, including low-field magnetic susceptibility vs temperature, 174 isothermal remanent magnetization (IRM) acquisition, hysteresis measurements, and three- 
axis IRM demagnetization were also carried out on the fragments. These additional analyses constrain the nature and stability upon heating of their magnetic mineralogy.

\subsection{Magnetic mineralogy}

As a preliminary test for selecting the most promising fragments for intensity experiments, low-field magnetic susceptibility vs temperature curves were systematically acquired up to $\sim 530-550^{\circ} \mathrm{C}$ on the whole collection using a Kappabridge MFK1 coupled with a CS4 thermal unit (Agico, Czech Republic). The first objective of these measurements was to test the thermal stability of the magnetic mineralogy inferred from the reversibility between the heating and cooling curves over the typical temperature range of intensity determinations. This is the reason why the thermomagnetic analyses were essentially performed up to a temperature relatively close to $\mathrm{T} 2$. Every fragment that was retained displays reversible behavior in susceptibility, as in Fig. 4a-e, whereas Fig. 4f illustrates a rejected fragment. We note that only two fragments were rejected at this step, which indicates magnetic stability upon heating of our collection of bricks. For a few fragments successfully analyzed in intensity, additional thermomagnetic measurements were also conducted at higher temperatures on new fresh powders, up to $700^{\circ} \mathrm{C}$ (insets in Fig. 4). They show a clear inflexion point between $\sim 520^{\circ} \mathrm{C}$ and the Curie temperature of magnetite. The presence of hematite is also implied in several fragments (e.g. Fig. 4b).

In order to decipher the nature of the magnetic carriers in the fragments that met our archeointensity selection criteria, IRM and hysteresis measurements were performed on all the retained fragments. They were carried out up to $0.9 \mathrm{~T}$ using a Variable Field Translation Balance (VFTB; Peterson Instruments, Germany). IRM curves show that the magnetization is never saturated at $0.9 \mathrm{~T}$, which indicates the presence of minerals with high-coercivity, such as hematite (Fig. 5a). We observe, however, a high variability in the IRM behavior. This 
200 indicates variable proportions of this high-coercivity fraction against one characterized by 201 lower coercivity. Some fragments (for instance PP01-05; PP01-12; BGA01-02; Fig. 5a) 202 clearly exhibit around 0.1-0.2 $\mathrm{T}$ a plateau or a sharp inflection in the saturation curves. This 203 likely emphasizes the joint presence of minerals from the (titano)magnetite family. In all 204 cases, the hysteresis loops are constricted (Fig. 5b-d): this confirms that the magnetic 205 mineralogy of our fragments consists of minerals with different coercivities. For fragments fulfilling our archeointensity selection criteria (except six of them for 207 which not enough material was remaining), we completed the previous measurements with 208 thermal demagnetization of a three-axis IRM (1.2T, 0.4T, 0.2T) imparted in perpendicular 209 directions (Lowrie, 1990). Three main categories of behavior are distinguished. In the first 210 category (Fig. 5e), the low-coercivity fraction, most likely consisting of (titano)magnetite, 211 largely dominates any other component of the magnetic mineralogy. The thermal 212 demagnetization of this fraction is achieved around $550^{\circ} \mathrm{C}$. This category represents about $21320 \%$ of the collection of fragments. In the second category (Fig. 5f), which is most frequent in 214 our collection (about 50\%), there is a higher proportion of high-coercivity minerals that is 215 demagnetized around $200^{\circ} \mathrm{C}$. This fraction is sometimes as large as that of low coercivity. In 216 this case, the low-coercivity fraction predominates the magnetic signal between $\sim 200^{\circ} \mathrm{C}$ and $217500 / 550^{\circ} \mathrm{C}$. Although the presence of goethite cannot be excluded in our fragments on the 218 basis of these experiments, it seems more probable that we observe the mineral of high 219 coercivity and low unblocking temperature (HCLT), which is commonly present in 220 archeological baked clays (e.g. McIntosh et al., 2011; Hartmann et al., 2011; Genevey et al., 221 2016). Lastly, the third category (about $30 \%$ of the collection) is characterized by a high222 coercivity fraction, which remains present, and in a few cases, predominates the 223 magnetization throughout the thermal demagnetization sometimes achieved above $600^{\circ} \mathrm{C}$ 224 (Fig. 5g). Over a wide temperature range, the magnetization is thus carried both by low- 
coercivity and high-coercivity minerals, which are most likely composed of (titano)magnetite and hematite.

As a synthesis, the rock magnetic analyses indicate that the magnetic mineralogy of our fragments includes three types of minerals with different coercivities and different unblocking temperatures in various proportions. These are likely (titano)magnetite, hematite, and the HCLT mineral. The latter can be a substituted form of hematite. It is worth mentioning that a similar combination of magnetic carriers is commonly found in archeomagnetic studies (e.g. Genevey et al., 2016).

Finally, we performed a series of specific archeointensity experiments on fragments belonging to the third IRM category described above. The aim was to ensure that, despite a significant proportion of hematite, these fragments provide a reliable value of the ancient geomagnetic field intensity. For these fragments, which are characterized by a magnetic mineralogy stable upon heating, a total pseudo-NRM was first acquired in a known laboratory field condition. In a second step, classical Triaxe archeointensity measurements were performed to analyze this pseudo-NRM. The latter allow to recover very precisely, to within a few $\%$, the value of the field intensity used for the pseudo-NRM acquisition (Fig. S1 in supplementary material). These measurements therefore demonstrate that the hematite-related magnetization component does not significantly disturb the determination of the ancient field intensity that it is likely conveyed by the magnetization carried by (titano)magnetite.

\subsection{Cooling rate effect on TRM acquisition}

In several specimens, a rather specific behavior of the $\mathrm{R}(\mathrm{Ti})$ and $\mathrm{R}$ '(Ti) data was observed, that is characterized first, by a significant increase of the R(Ti) data with the temperatures and second, by a pronounced concave evolution of the R'(Ti) data (see two 
examples in Fig. 6a,c). In several cases, the strong concavity of the R'(Ti) curves implied the 250 rejection of the corresponding specimens.

Per the experiments performed by Le Goff et Gallet (2004), the significant increase in

$\mathrm{R}(\mathrm{Ti})$ data led us to suspect a strong cooling rate effect on TRM acquisition (see Section 5 and Fig. 4 in Le Goff and Gallet, 2004, and in Genevey et al., 2008 for a more general discussion on the cooling effect on TRM acquisition). It is worth recalling that Le Goff and Gallet (2004) experimentally observed that the increasing trend in $\mathrm{R}(\mathrm{Ti})$ data can be linked to the fact that the cooling rate effect becomes stronger as the magnetization fractions with unblocking temperatures between Ti and T2 gradually decrease. Le Goff and Gallet (2004)

258 further showed that this difficulty can be circumvent by considering R'(Ti) data relying on the 259 magnetization fractions unblocked between $\mathrm{T} 1$ and Ti. In the present study, however, it was 260 important to confirm this characteristic because the cooling rate effect appeared potentially 261 strong. For this reason, we analyzed many fragments using (for different specimens) two 262 cooling rates for the laboratory-TRM acquisition: 1- the one used for routine measurements 263 carried out using the Triaxe, i.e. with a cooling rate fixed to $25^{\circ} \mathrm{C} /$ minute and 2- a cooling rate 264 reduced to $2^{\circ} \mathrm{C} /$ minute (see details in Table $\mathrm{S} 1$ in supplementary material). In the latter case, 265 the R'(Ti) data often exhibit a more suitable behavior with more constant values, while the $266 \mathrm{R}(\mathrm{Ti})$ data show less increase over the temperature interval of analysis (Fig. 6b,d).

We then directly compared the intensity values computed at the group level (Fig. 7) 268 using either the $25^{\circ} \mathrm{C} /$ minute cooling rate or the $2^{\circ} \mathrm{C} /$ minute cooling rate. This comparison 269 shows no statistical significance in the difference, which remains within 5\% when the 270 intensity determinations obey our selection criteria. Moreover, on average (31 fragments) the 271 differences in intensity at the fragment level relative to the values obtained using a cooling 272 rate of $25^{\circ} \mathrm{C} /$ minute are also insignificant: $1.5 \pm 2.8 \%$. Nevertheless, the use of a slow cooling 273 rate of $2^{\circ} \mathrm{C} /$ minute allowed us to retain several fragments that would have been rejected 
274 otherwise. This led us to retain the group of fragments GYU01, for which one fragment 275 among the three was only successfully analyzed using the slow cooling rate (GYU01-04;

276 Table S1 in supplementary material). Hereafter, we will therefore determine mean intensity

277 values at the fragment level by combining the values obtained whatever the cooling rate 278 applied. Finally we note that for some specimens, T2 was chosen relatively low $\left(440^{\circ} \mathrm{C}\right.$;

279 Table S1 in supplementary material), assuming that the cooling rate dependence on TRM 280 acquisition was more pronounced for the magnetization fraction unblocked at high 281 temperatures (Le Goff and Gallet, 2004).

\subsection{Archeointensity data}

Our experiments allowed us to obtain archeointensity data satisfying our selection criteria from 165 specimens (of a total of 337 specimens whose magnetization was strong enough for the Triaxe magnetometer). These specimens are from 40 different fragments, with usually 3 to 4 specimens successfully analyzed per fragment (see Table 1 in Supplementary material). This corresponds to a rate of success comprised between $42 \%$ and $67 \%$ depending on the groups of fragments (Table S1 in supplementary material). Failures were linked, in equal proportion, to a strong concavity of the R'(Ti) curve (Fig. 6c), a large slope of the

$291 \mathrm{R}$ '(Ti) curve or to a difference between specimen values from a same fragment larger than our $2925 \%$ limit. Typical examples of thermal demagnetization data for successful specimens are 293 reported in Fig. S2 (in supplementary material). Mean intensity values were derived for nine 294 groups of fragments, with a minimum number of three fragments per group (VS01, GYU01). 295 This number increases up to five for four groups (DM03, DM02, BGA01, SH01) and six for 296 group PP01. Fig. 8 illustrates the archeointensity data obtained from six different groups of 297 fragments (one panel per group). In this representation, each curve exhibits the R'(Ti) data 298 obtained for one specimen. The curves also represent the scatter in the data obtained from 
each group. Here, we observe that the variability is quite weak, which was expected given the excellent temporal homogeneity of the fragments from each group.

As in all the previous studies dealing with Triaxe intensity data (e.g. Genevey et al,

2013; Gallet et al, 2014), we estimated a mean archeointensity value for each group of averaging of these specimen values at the level of each fragment, and finally the averaging of the fragment values at the group level. The group-mean archeointensity results are well defined, with standard deviations consistently less than $2.6 \mu \mathrm{T}$ and not exceeding $5 \%$ of the corresponding group-mean value (between $1.2 \%$ and $4.2 \%$ ). They range from $66.1 \pm 1.9 \mu \mathrm{T}$ to $48.7 \pm 1.6 \mu \mathrm{T}$, with an overall decrease of the geomagnetic field intensities between the 12th and 17th centuries AD (Table 1; Fig. 9).

\section{Discussion}

Fig. 9a shows the data available within a radius of $700 \mathrm{~km}$ around Novgorod (grey dots). Apart from the new archeointensity results reported in the present study, the previous data were principally obtained from two areas (Fig. 1a) around Moscow and Vologda ( 500 km from Novgorod). Although the data were obtained over 30-years-ago (Burlatskaya et al., 1986), partial-TRM checks were used most often to test the stability of the magnetic mineralogy on heating (Genevey et al., 2008). Here we only retained the data with partialTRM checks and those for which the standard deviation is less than $15 \%$ of the corresponding mean intensity value. Note that the corresponding fragments were collected from architectural bricks, a material for which the TRM anisotropy effect is expected to be weak (e.g. Genevey et al., 2008). A color code in Fig. 9a allows one to distinguish between results obtained from two or more independent archeological artifacts. Two main remarks can be made about these data. Firstly, within the $\sim 1500-1800$ AD time interval, they are very scattered regardless of 
324 the number of fragments or specimens used to estimate the mean intensity values, which 325 prevents a clear determination of the geomagnetic field intensity evolution. Such a scatter 326 clearly casts doubt on the reliability of at least some of these data. Secondly, no result was available up to now from North-Western Russia for the 1000-1400 AD time interval. While our new data exhibits an overall decreasing trend in geomagnetic field intensity over the time interval of concern, they do not show a variability that could indicate the occurrence of rapid and large-amplitude intensity fluctuations in North-Western Russia 331 during the past millennium. In this respect, although it is acknowledged that the present dataset contains only nine archeointensity values, they do not corroborate the large variations observed in the Balkan region (700 km around Thessaloniki; Tema and Kondopoulou, 2011;

334 Kovacheva et al., 2014). This difference is illustrated in Fig. 9a, where the Balkan data (light violet squares) are reported after their transfer to the latitude of Novgorod using the Virtual Axial Dipole Moment approximation. Here we recognize that this approach adds uncertainties on the transferred values (e.g. Casas and Incoronato, 2007); however we assume that they

338 remain relatively limited compared to the experimental and age uncertainties of the data. For 339 the latter dataset, a color code is used to distinguish between results with and without partial340 TRM checks (see discussion in Genevey et al., 2013; 2016). This distinction does not, 341 however, allow one to detect any difference in the nature of the intensity fluctuations in the 342 Balkans. In contrast, the Novgorod results appear in better agreement with the average 343 geomagnetic field intensity variation curve for Western Europe (700 km around Paris; blue 344 curve in Fig. 9a), also transferred to the latitude of Novgorod, determined by Genevey et al. 345 (2013; 2016). However, the available data are still not numerous enough to show the 346 occurrence of similar short-lasting relative maxima in North-Western Russia as those 347 observed in Western Europe, i.e. dated from the 12th century, the second half of the 14th 348 century and around 1600 AD (Genevey et al., 2016). At present, the archeointensity dataset 
from the Novgorod area is more compatible with homogeneous geomagnetic field intensity variations throughout Europe over the past millennium (e.g. Pavón-Carrasco et al., 2014a). In Fig. 9b, the new archeointensity data are also compared with the expected intensity values computed at Novgorod from recent global archeomagnetic field models (i.e. A_FM, Licht et al., 2013; SCHA_DIF.14k, Pavón-Carrasco et al., 2014b; pfm9k.1a, Nilsson et al., 2014). Note that the curve derived from pfm9k.1a (brown curve) displays smoother variations than those from the two other models (green curve, A_FM; orange curve, SCHA-DIF.14k), which is due to the use of sedimentary, volcanic and archeological data by Nilsson et al. (2014) (for instance, see discussion in Licht et al., 2013). Nevertheless, in all three cases, the models quasi-systematically predict intensity values that are statistically higher than the data obtained in the Novgorod area. This indicates that the global field models need to be revised to correct for this intensity over-estimation in North-Western Russia. It is possible that at least 361 a part of this offset originates from the cooling rate effect, which was considered only for a 362 small proportion of the archeointensity data used for field modeling (Genevey et al., 2008; 363 Brown et al., 2015). The most recent archeointensity result obtained in Novgorod, i.e. from group DM03 365 precisely dated to the end of the 17th century (Table 1), is also of special interest for field 366 modeling. Its value is lower by $\sim 5 \mu \mathrm{T}$ than the expected intensity around the same epoch 367 which was derived from the historical geomagnetic field modeling referred to as gufm1 (black 368 curve in Fig. 9b; Jackson et al., 2000). Briefly, it is worth recalling that the latter field models 369 were built using magnetic field measurements made by mariners and performed in a few land 370 observatories (e.g., Jonkers et al., 2003), and assuming a linearly decreasing geocentric axial 371 dipole field moment (term $g_{1}^{0}$ ) from $\sim 1600$ AD to the present (Barraclough, 1974). Such 372 hypothesis made for the 1600-1840-time interval (i.e. beyond the first direct intensity 373 measurements) is not confirmed here. Even though differences appear less pronounced, our 
374 value also fails to confirm a constant -or nearly constant $g_{1}^{0}$ evolution between $\sim 1600$ and 375 1840, as previously proposed by Finlay (2008) and Gubbins et al. (2006), respectively (Fig. $3769 \mathrm{~b})$. On the other hand, its age cannot help deciphering the oscillatory $g_{1}^{0}$ evolution suggested 377 by Genevey et al. (2009) over the past four centuries (see also Hartmann et al., 2011 for 378 Brazilian data). More archeomagnetic data are clearly needed to strengthen this important 379 issue.

\section{Conclusions}

This study is part of a project, which aims to acquire archeomagnetic data acquisition from Central and North-Western Russia. Previous studies were consistently made during the 70s and 80s, but unfortunately stopped for many years. At the same time, other Western Eurasian regions benefited from a strong development in archeomagnetism research activity. churches in the Novgorod area. These groups are precisely dated between the 12th and 17th century AD.

Archeointensity analyses were carried out using the experimental protocol developed for the Triaxe magnetometer. They allow us to obtain nine new mean archeointensity data,

391 derived from 40 different fragments and 165 analyzed specimens.

These data show an overall decreasing trend in geomagnetic field intensity over the 393 past millennium, with no evidence of rapid variations with large amplitude such as those 394 proposed from the Balkans (e.g. Tema and Kondopoulou, 2011; Kovacheva et al., 2014). 395 They are more compatible with the French geomagnetic field intensity variation curve 396 proposed by Genevey et al. (2016), after its transfer to the latitude of Novgorod. Should this result persist in future archeointensity data collections and analyses, the intensity secular 
398 variation would have remained homogeneous across all Europe during at least the past 399 millennium.

An intriguing observation is that our Novgorod results are lower than the intensity

401 values predicted from archeomagnetic field models. We suggest that the observed differences, 402 at least in part, originate from the cooling rate effect on TRM acquisition, the latter not 403 considered in most of the data used for the construction of the models.

404 Finally, we note that a result dated to the end of the $17^{\text {th }}$ century is not compatible with 405 the expected intensity value derived from the gufm1 model (Jackson et al., 2000), which assumes a linear decrease of the axial dipole moment over the past four centuries.

\section{Acknowledgments}

This study was financed by grant N 14.Z50.31.0017 of the Russian Ministry of Science and

Education. We are very grateful to Maxime Le Goff for his unwavering technical assistance.

We thank two anonymous reviewers for their helpful comments. This is IPGP contribution no. 3842 .

\section{References}

Aitken, M. J., Allsop, A. L., Bussell, G. D., Winter, M. B., 1988. Determination of the intensity of the Earth's magnetic field during archaeological times: Reliability of the

Aitken, M. J., Allsop, A. L., Bussell, G. D., Liritzis, Y., Winter, M. B., 1989. Geomagnetic intensity measurements using bricks from Greek churches of the first and second millennia A.D.. Archaeometry 31, 77-87. 
Antipov, I., Gervais, A., 2015. The bricks from St Nicholas church at Lipno near Novgorod (1292) and the origins of the new Novgorodian building tradition. Estonian Journal of Archaeology 19, 58-7.

Barraclough, D., 1974. Spherical harmonic analysis of the geomagnetic field for eight epochs between 1600 and 1910. Geophys. J. R. Astron. Soc. 43, 497-513.

Brown, M. C., Donadini, F., Korte, M., Nilsson, Korhonen, K., Lodge, A., Lengyel, S. N., Constable, C. G., 2015. GEOMAGIA50.v3: 1. General structure and modifications to the archeological and volcanic database. Earth Planet and Space 67, 1-31.

Burlatskaya, S. P., Nachasova, I.E., Didenko, E. J., Shelestun, N. K., 1986. Archeomagnetic determinations of geomagnetic field elements. Sov. Geophys. Comm. of the USRR Acad. of Sci., Moscow.

Casas, L., Incoronato, A., 2007. Distribution analysis of errors due to relocation of geomagnetic data using the 'Conversion via Pole' (CVP) method: implications on archeomagnetic data. Geophys. J. Int. 169, 448-454.

Coe, R. S., 1967. Paleo-Intensities of the Earth's magnetic field determined from Tertiary and Quaternary Rocks. J. Geophys. Res. 72, 3247-3262.

De Marco, E., Spatharas, V., Gómez-Paccard, M., Chauvin, A., Kondopoulou, D., 2008. New archaeointensity results from archaeological sites and variation of the geomagnetic field intensity for the last 7 millennia in Greece. Phys. Chem. Earth 33, 578-595.

Finlay, C.C., 2008. Historical variation of the geomagnetic axial dipole. Phys. Earth Planet. Inter. 170, 1-14.

Gallet, Y., Genevey, A., Le Goff, L., 2002. Three millennia of directional variation of the Earth's magnetic field in western Europe as revealed by archeological artefacts. Phys. Earth Planet. Inter. 131, 81-89. 
445 Gallet, Y., Le Goff, M., 2006. High-temperature archeointensity measurements from 446 Mesopotamia. Earth Planet. Sci. Lett. 241, 159-173.

447 Gallet, Y., Genevey, A., Le Goff, M., Warmé, N., Gran-Aymerich, J., Lefèvre, A., 2009. On the use of archeology in geomagnetism, and vice-versa: Recent developments in archeomagnetism. C. R. Physique, 10 630-648.

Gallet, Y., D’Andrea, M., Genevey, A., Pinnock, F., Le Goff, M., Matthiae, P., 2014. Archaeomagnetism at Ebla (Tell Mardikh, Syria). New data on geomagnetic field intensity variations in the Near East during the Bronze Age. J. Archaeol. Sci. 42, 295304.

Genevey, A., Gallet, Y., Constable, C., Korte, M., Hulot, G., 2008. ArcheoInt: An upgraded compilation of geomagnetic field intensity data for the past ten millennia and its application to the recovery of the past dipole moment. Geochem. Geophys. Geosys. 9(4), Q04038.

Genevey, A., Gallet, Y., Rosen, J., Le Goff, M., 2009. Evidence for rapid geomagnetic field intensity variations in Western Europe over the past 800 years from new archeointensity French data. Earth Planet. Sci. Lett. 284, 132-143.

Genevey, A., Gallet, Y., Thébault, E., Jesset, S., Le Goff, M., 2013. Geomagnetic field intensity variations in Western Europe over the past 1100 years. Geochem. Geophys. Geosyst. 14/8, 2858-2872.

464 Genevey, A., Gallet, Y., Jesset, S., Thébault, E., Bouillon, J., Lefèvre, A., Le Goff, M., 2016. 465 New archeointensity data from French Early Medieval ceramic production (6th-10th century AD). Tracing 1500 years of geomagnetic field intensity variations in Western Europe. Phys. Earth Planet. Inter. 257, 205-219. 
Gervais, A. V., Lipatov A. A., 2003. The interpretation problems of the kiln near the Annunciation church on Gorodishche (in Russian). In Novgorod i Novgorodskaia zemlia. Istoria i archeologia. V. Novgorod 17, 344-350.

Gómez-Paccard, M., Chauvin, A., Lanos, P., Thiriot, J., 2008. New archeointensity data from Spain and the geomagnetic dipole moment in western Europe over the past 2000 years. J. Geophys. Res., 113, B09103.

Gómez-Paccard, M., Chauvin, A., Lanos, P., Dufresne, P., Kovacheva, M., Hill, M. J., Beamud, E., Blain, S., Bouvier, A., Guibert, P., and Archaeological Working Team, 2012. Improving our knowledge of rapid geomagnetic field intensity changes observed in Europe between 200 and 1400 AD. Earth Planet. Sci. Lett. 355-356, 131-143.

Gómez-Paccard, M., Osete, M.L., Chauvin, A., Pavón-Carrasco F.J., Pérez-Asensio, M., Jiménez, P., Lanos, P, 2016. New constraints on the most significant paleointensity change in Western Europe over the last two millennia. A non-dipolar origin?. Earth Planet. Sci. Lett. 454, 55-64.

Gubbins, D., Jones, A.L., Finlay, C.C., 2006. Fall in Earth's magnetic field is erratic. Science $312,900-902$.

Hartmann, G., Genevey, A., Gallet, Y., Trindade, R., Etchevarne, C., Le Goff, M., Afonso, M., 2010. Archeointensity in Northeast Brazil over the past five centuries. Earth Planet. Sci. Lett. 296, 340-352.

Hartmann, G., Genevey, A., Gallet, Y., Trindade, R., Le Goff, M., Najjar, R., Etchevarne, C., Afonso, M., 2011. New historical archeointensity data from Brazil : Evidence for a large regional non-dipole field contribution over the past few centuries. Earth Planet. Sci. Lett. 306, 66-76. 
Hervé, G., Chauvin, A. Lanos P., 2013a. Geomagnetic field variations in Western Europe from $1500 \mathrm{BC}$ to $200 \mathrm{AD}$. Part I: Directional secular variation curve. Phys. Earth Planet. Inter. 218, 1-13.

Hervé, G., Chauvin, A. Lanos P., 2013b. Geomagnetic field variations in Western Europe from $1500 \mathrm{BC}$ to $200 \mathrm{AD}$. Part II: New intensity secular variation curve. Phys. Earth Planet. Inter. 218, 51-65.

Hervé, G., Chauvin, A., Milcent, P.-Y., Tramon, A., 2016. Archaeointensity study of five Late Bronze Age fireplaces from Corent (Auvergne, France). J. Archaeol. Sci.: Reports 7, 414-419.

Jackson, A., Jonkers, A., Walker, M., 2000. Four centuries of geomagnetic secular variation from historical records. Philos. Trans. R. Soc. Lond. Ser. A 358, 957-990.

Jonkers, A. R. T., Jackson, A., Murray, A., 2003. Four centuries of geomagnetic data from historical records. Rev. Geophys. 41, 1006.

Kovacheva, M., Boyadziev, Y., Kostadinova-Avramova, M., Jordanova, N., Donadini, F., 2009. Updated archeomagnetic data set of the past eight millennia from the Sofia laboratory, Bulgaria. Geochem. Geophys. Geosyst. 10, Q05002, doi:10.1029/2008GC002347.

Kovacheva, M., Kostadinova-Avramova, M., Jordanova, N., Lanos, P., Boyadziev, Y., 2014. Extended and revised archaeomagnetic database and secular variation curves from Bulgaria for the last eight millennia. Phys. Earth Planet. Inter. 236, 79-94, doi: 10.1016/j.pepi.2014.07.002.

Le Goff, M., Gallet, Y., 2004. A new three-axis vibrating sample magnetometer for continuous high-temperature magnetization measurements: applications to paleo- and archeo-intensity determinations. Earth Planet. Sci. Lett. 229, 31-43. 
515 Licht, A., Hulot, G., Gallet, Y., Thébault, E., 2013. Ensembles of low degree archeomagnetic field models for the past three millennia. Phys. Earth Planet. Inter. 224, 38-67.

517 Lipatov, A. A., 2005. The kiln from Gorodishche (1988 excavations) in the context of lime manufacturing in Byzantine, Western Europe and Ancient Russia (in Russian). In Nosov E. N., Gorunova V.M., Plokhov A.V. Eds., Gorodishche pod Novgorodom i

Lowrie, W., 1990. Identification of ferromagnetic minerals in a rock by coercivity and unblocking temperatures properties. Geophys. Res. Lett., 17, 159-162.

McIntosh, G., Kovacheva, M., Catanzariti, G., Donadini, F., Lopez, M. L. O., 2011. High coercivity remanence in baked clay materials used in archeomagnetism. Geochem.

Michell, R., Forbes, N., 1914. The chronicle of Novgorod 1016-1471 (translated from the Russian). Camden Third Series Vol. XXV, London Office of the Society, pp. 237.

Nachasova, I. YE., 1972. Magnetic field in the Moscow area from 1480 to 1840 (Engl. Transl). Geomagn. Aeron. 12, 277-280.

Nasonov A. N. (Ed.), 1950. Novgorodskaya Pervaya letopis (in Russian). Izdatelstvo Akademii nauk SSSR, Moscow- Leningrad, pp. 642.

Nilsson, A., Holme, R., Korte, M., Suttie, N., Hill, M., 2014. Reconstructing Holocene geomagnetic field variation: New methods, models and implications, Geophys. J. Int.

536 Pavón-Carrasco, F. J., Gómez-Paccard, M., Hervé, G., Osete López, M.L., and A. Chauvin, A., 2014a. Intensity of the geomagnetic field in Europe for the last $3 \mathrm{ka}$ : Influence of 
data quality on geomagnetic field modeling. Geochem. Geophys. Geosyst. 15, 25152530.

Pavón-Carrasco, F. J., Osete López, M. L., Torta, J. M., De Santis, A., 2014b. A geomagnetic field model for the Holocene based on archaeomagnetic and lava flow data. Earth Planet. Sci. Lett. 388, 98-109.

Pesonen, L. J., Leino, M. A. H., Nevanlinna, H., 1995. Archaeomagnetic intensity in Finland during the last 6400 years: Evidence for a latitude-dependent nondipole field at approximately AD 500. J. Geomagn. Geoelectr. 47, 19-40.

Rybina, E. A., 1992. Trade links of medieval Novgorod established through archaeological data. In: The archaeology of Novgorod, Russia. Recent results from the town and its hinterland. Eastern Press, Ltd, Lincoln, 193-205.

Rybina, E. A., 2001. Frühe “joint-ventures”. Die Beziehungen Novgorods im Ostseeraum. In: M. Müller-Wille u.a. (Hrsg.), Novgorod. Das mittelalterliche Zentrum und sein Umland im Norden Russlands. Studien zur Siedlungsgeschicgte und Archäologie der Ostseegebiete. 1. Neumünster, 291-308.

Spassov, S., Valet, J.-P. , Kondopoulou, D., Zananiri, I., Casas, L., Le Goff, M., 2010. Rock magnetic property and paleointensity determination on historical Santorini lava flows. Geochem. Geophys. Geosyst. 11, Q07006, doi:10.1029/2009GC003006.

Tema, E., Kondopoulou, D., 2011. Secular variation of the Earth's magnetic field in the Balkan region during the last eight millennia based on archaeomagnetic data. Geophys. J. Int. 186(2), 603-614.

Tema, E., Gómez-Paccard , M., Kondopoulou, D., Ylenia, A., 2012. Intensity of the Earth's magnetic field in Greece during the last five millennia: New data from Greek pottery. Phys. Earth Planet. Inter. 202-203, 14-26. 
Tema, E., Morales, J., Goguitchaichvili, A., Camps, P., 2013. New archaeointensity data from Italy and geomagnetic field intensity variation in the Italian Peninsula. Geophys. J. Int. $193,603-614$.

Thellier, E., Thellier, O., 1959. Sur l'intensité du champ magnétique tesrrestre dans le passé historique et géologique. Ann. Géophys. 15, 285-376.

Yu, Y., Tauxe, L., Genevey, A., 2004. Toward an optimal geomagnetic field intensity determination technique. Geochem. Geophys. Geosyst., 5, Q02H07.

\section{Figure captions}

Fig. 1 (a) Location map of the city of Novgorod. (b) Map that identifies the location of groups of architectural brick fragments collected in the Novgorod area. 1- Church of the Annunciation in the Gorodishche (group BGA01), 2- Monastery church of St. Georgi (group GYU01), 3- Church to the Holy Apostels Peter and Paul in Silnishche (group PP01), 4Transfiguration church on Nereditsa hill (group SN01), 5- Holy Virgin Protection church of Shilov Monastery (group SH01), 6,9- Church of the Holy Resurrection on the Derevyanitsa river (groups DM02 and DM03), 7- Church of St. Andrew the Holy Fool on Sitka (group AS01), 8- Cathedral of Our Lady of Vladimir of Syrkov Monastery (group VS01).

581 Fig. 2 Examples of dating via details found in the Novgorod First Chronicle (translation from

582 Michell and Forbes, 1914) for two of our groups of brick fragments. (a) Dating of the church 583 of the Annunciation in the Gorodishche (BGA01). (b) Dating of the church of the Holy 584 Apostels Peter and Paul in Silnishche (PP01). 
Fig. 3 Archeological context of four groups of brick fragments. (a) SN01; (b) DM02; (c) AS01; (d) SH01. See details in Fig. 1 and Table 1.

Fig. 4 Examples of low-field magnetic susceptibility versus temperature curves for our collection of fragments. The heating/cooling curves are in red/blue. The maximum temperatures were chosen relatively close to temperature T2 used for archeointensity experiments (see text). The data shown in the insets were obtained on fresh powders from the same fragments up to $700^{\circ} \mathrm{C}$.

Fig. 5 IRM experiments conducted on the fragments fulfilling the criteria used to select the archeointensity results. (a) IRM curves obtained up to $0.9 \mathrm{~T}$ (see color code in the Figure). (bd) Examples of hysteresis loops illustrating the three categories of IRM behavior discussed in the text. (e-g) Examples of thermal demagnetization of three-axis IRM acquired along three perpendicular directions (1.2 T, 0.4 T, 0.2 T; Lowrie, 1990).

600

601 Fig. 6 Cooling rate effect on the shape of the R(Ti) and R'(Ti) curves for fragments PP01-04 602 $(a, b)$ and AS01-04 (c,d). The data were obtained using a cooling rate of $25^{\circ} \mathrm{C} /$ minute $(a, c)$ vs a cooling rate of $2^{\circ} \mathrm{C} /$ minute $(\mathrm{b}, \mathrm{d})$. In red (resp. black) the $\mathrm{R}^{\prime}(\mathrm{Ti})$ (resp. $\mathrm{R}(\mathrm{Ti})$ ) data (Le Goff 604 and Gallet, 2004). See text for further explanations.

605

606 Fig. 7 Comparison between group-mean intensity values estimated using cooling rates of $60725^{\circ} \mathrm{C} /$ minute and $2{ }^{\circ} \mathrm{C} /$ minute. The different symbols distinguish between mean intensity 608 values determined at the fragment group level from a minimum of three different fragments 609 (black dots) or from only two fragments (white dots; see supplementary Table S1). 
611 Fig. 8 Archeointensity results obtained for six different groups of brick fragments. In each

612 panel, each curve represents the R'(Ti) data obtained for one specimen (see color code on the

613 figure). These data are first averaged at the specimen level, then a mean intensity value is

614 estimated at the fragment level and the latter are averaged at the group level.

615

616 Fig. 9 Geomagnetic field intensity variations in the North-Western part of Russia over the 617 past millennium. (a) Our new archeointensity data (red diamond) are compared with the data 618 transferred to the latitude of Novgorod presently available within a radius of $700 \mathrm{~km}$ around 619 Novgorod (grey dots, Nachasova, 1972; Burlatskaya et al., 1986; Pesonen et al., 1995; 620 Kovacheva et al., 2009) and from the Balkans (light violet squares, Aitken et al., 1988, 1989; 621 De Marco et al., 2008; Spassov et al., 2010; Kovacheva et al., 2014). The blue curve exhibits 622 the average intensity variation curve obtained for Western Europe (Genevey et al., 2016) after 623 its transfer to the latitude of Novgorod. (b) A comparison is also performed with the 624 geomagnetic field intensity values expected in Novgorod from different global 625 archeo/geomagnetic field models (see details and color code on the figure).

\section{Table caption}

Table 1 New archeointensity data obtained in Novgorod area. Location, name and dating of the different churches are indicated in columns 2 (Latitude), 3 (Longitude), 4 (Site) and 5

631 (Age). N/fragment $\left(6^{\text {th }}\right.$ column $)$ and $\mathrm{n} /$ specimen $\left(7^{\text {th }}\right.$ column $)$ : number of fragments and 632 specimens used for group-mean intensity computations. Fmean $\pm \sigma F(\mu T)$ ( $8^{\text {th }}$ column): mean 633 intensity and its standard deviation obtained for each group of brick fragments. 
638 Fig. S1 Archeointensity experiments performed on a pseudo-NRM acquired in known field conditions for two fragments (a) DM02-02 and (b) SH01-06 showing a large fraction of 640 magnetization carried by hematite. The pseudo-NRM was acquired in a field of $60 \mu \mathrm{T}$ and 641 using a cooling rate of $25^{\circ} \mathrm{C} /$ minute. Triaxe experiments were conducted using the same field 642 and cooling conditions. In red (resp. black) the R'(Ti) (resp. R(Ti)) data (Le Goff and Gallet, 643 2004). See text for further explanations

645 Fig. S2 Typical examples of thermal demagnetization of the NRM carried by specimens successfully analyzed using the Triaxe protocol (first series of measurements acquired in that protocol; see in Section 3.a and in Le Goff and Gallet, 2004). In each case, the red dot indicates the closest temperature to T1' used for archeointensity determinations.

Table S1 Archeointensity data obtained in Novgorod area both at the specimen and fragment levels. Column description: Fragment identification; Specimen identification; T1-T2, temperature interval (in ${ }^{\circ} \mathrm{C}$ ) for intensity determination; Hlab, laboratory field used for TRM acquisition in $\mu \mathrm{T}$; Cooling rate $\left({ }^{\circ} \mathrm{C} /\right.$ minute $)$, cooling rate used for TRM acquisition; NRM T1 (T1') (\%), fraction of NRM from T1' involved in intensity determination (with $\mathrm{T} 1<\mathrm{T} 1{ }^{\prime}<\mathrm{T} 2$ ); Slope R' (\%), slope of the R'(Ti) data within the temperature interval of analysis; F, intensity value in $\mu \mathrm{T}$ derived for each specimen; Fmean value per fragment $\pm \sigma \mathrm{H}$, mean intensity in $\mu \mathrm{T}$ 657 computed at the fragment level with its standard deviation. * $(\mathrm{N} 1 / \mathrm{N} 2 / \mathrm{N} 3), \mathrm{N} 1$ : number of 658 fragments investigated, N2: number of fragments whose magnetization was strong enough for 659 allowing Triaxe measurements, N3: number of fragments obeying our selection criteria. 
(a)

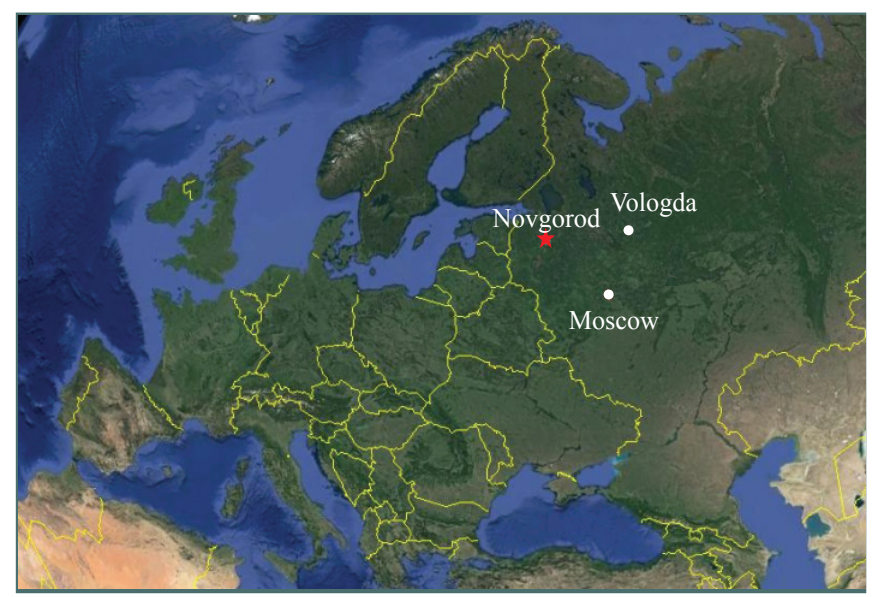

(b)

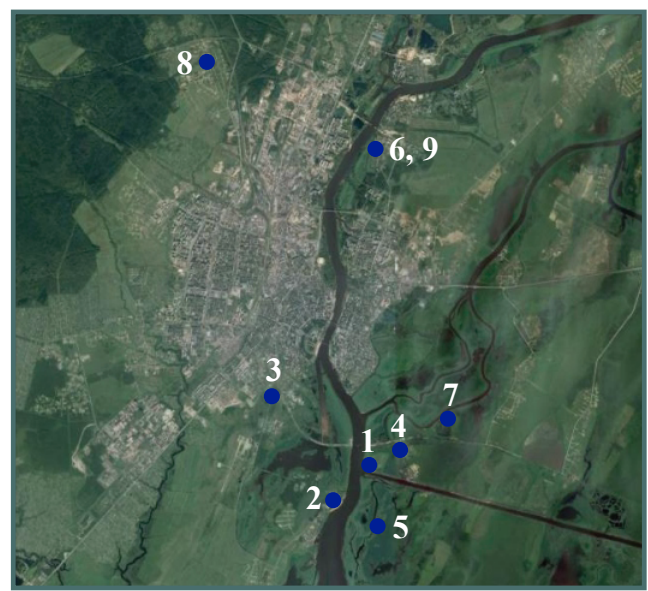

Figure 1 
(a)

A.D. 1103. A.M.6611 All the brethren Knyazes of the Russian Land went against the Polovets people to the Suten, and deleated them, and captured the belongings of their Knyaz. The same year the Mordva ${ }^{6}$ people defeated Yaroslav at Murom. The same year Knyaz Mstislav founded the Church of the Annunciation in the Gorodishche ${ }^{6}$. (b)

A.D. 1185. A.M. 6693

On the 1st day of May, at the 10th hour of the day, at evening bell, the sun grew dark, for an hour or more, and there were the stars; then it stone out again, and we were glad.

On the 6th of the same month the people of Luki founded a stone church to the holy Apostels Peter and Paul in Silnishche. The same year Miloneg founded the stone church of the Holy Ascension under Vladyka Ilya and Knyaz Mstislav Davidovits.

And in the winter David went Polotsk with the men of Novgorod and of Smolensk, and having made peace returned through Ymenets. 
(a)

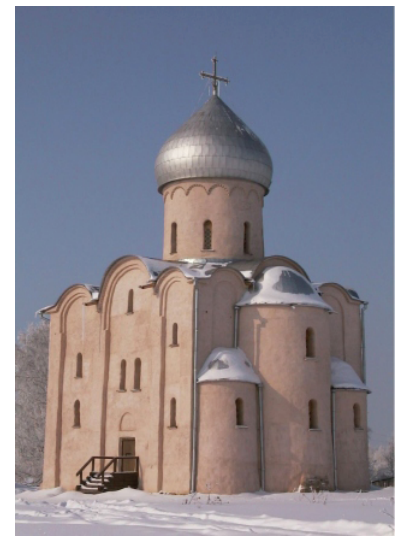

(b)

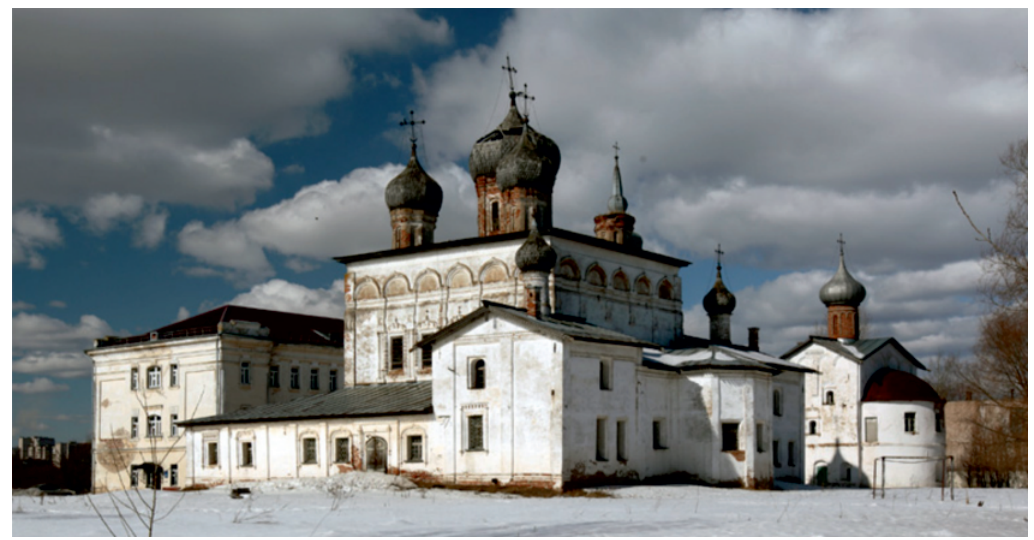

(c)

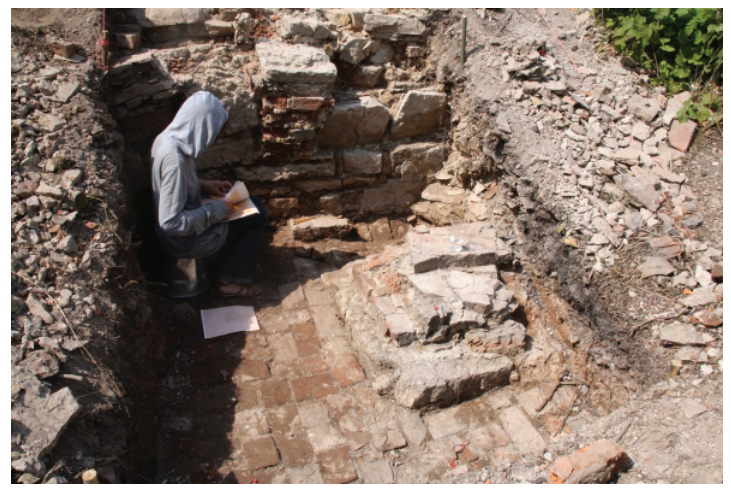

(d)

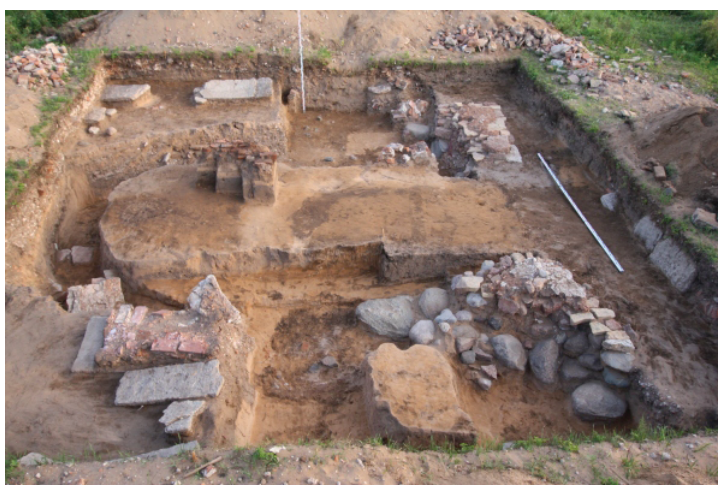

Figure 3 
(a) AS01-06

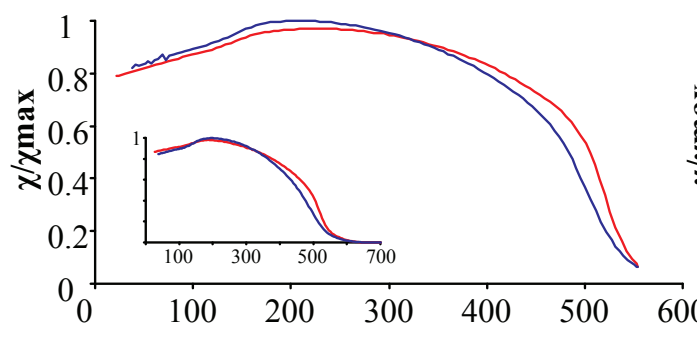

(c) DM02-07

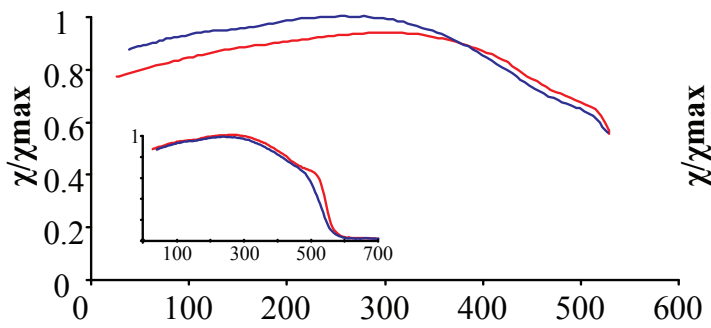

(e) AS01-05

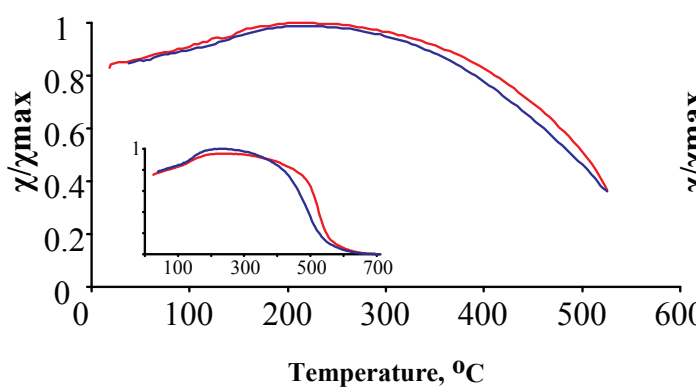

(b) GYU01-01

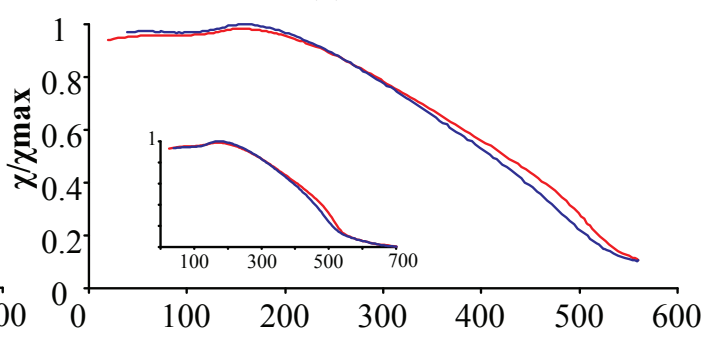

(d) SH01-11

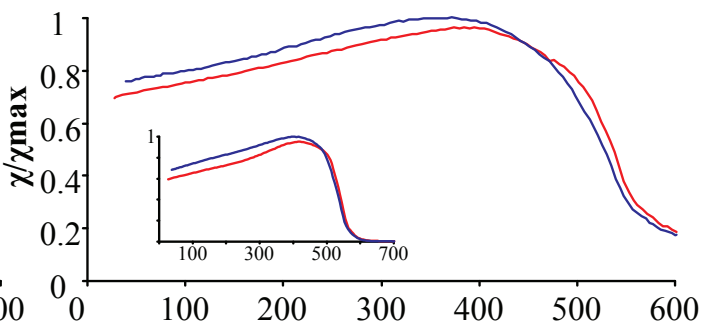

(f) $\mathrm{SH01-12}$

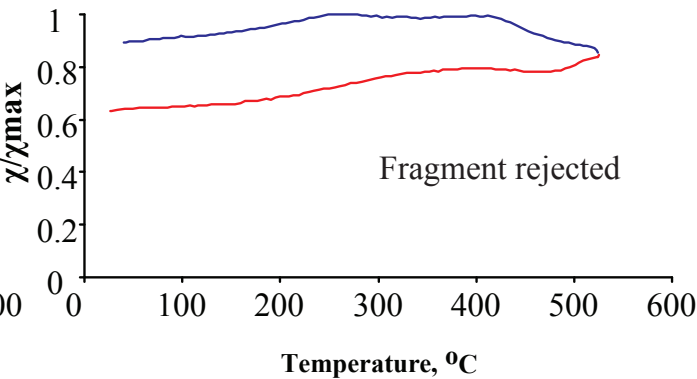

Figure 4 
(a)

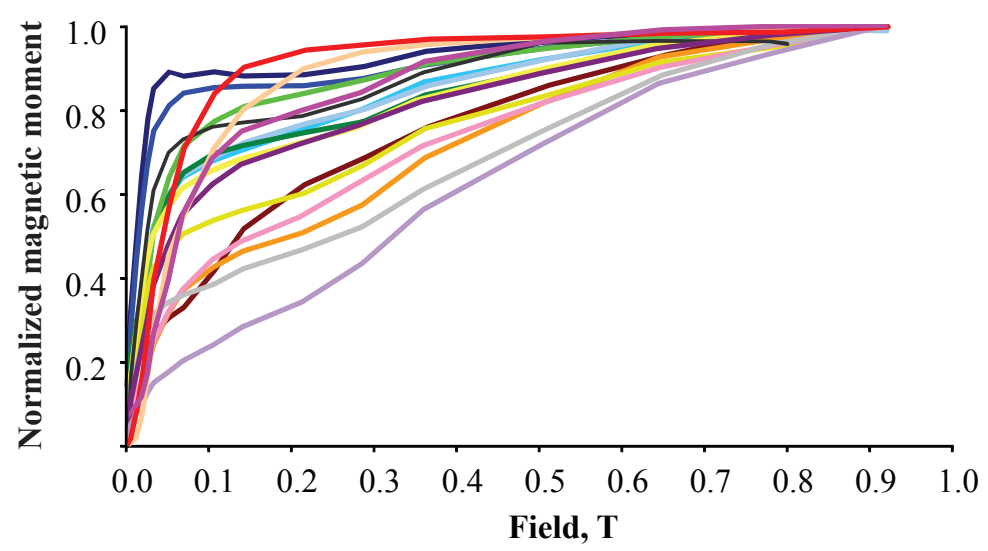

$$
\begin{aligned}
& \text { - BGA01-02 - SH01-11 } \\
& \text { - BGA01-03 - SN01-02 } \\
& \text { - PP01-05 - SN01-04 } \\
& \text { - PP01-12 }- \text { DM02-02 } \\
& \text { - GYU01-02 - DM02-08 } \\
& \text { - GYU01-07 - VS01-04 } \\
& \text { - AS01-05 }- \text { VS01-02 } \\
& \text { - AS01-08 - DM03-04 } \\
& \text { - SH01-03 - DM03-07 }
\end{aligned}
$$

(b) AS01-08

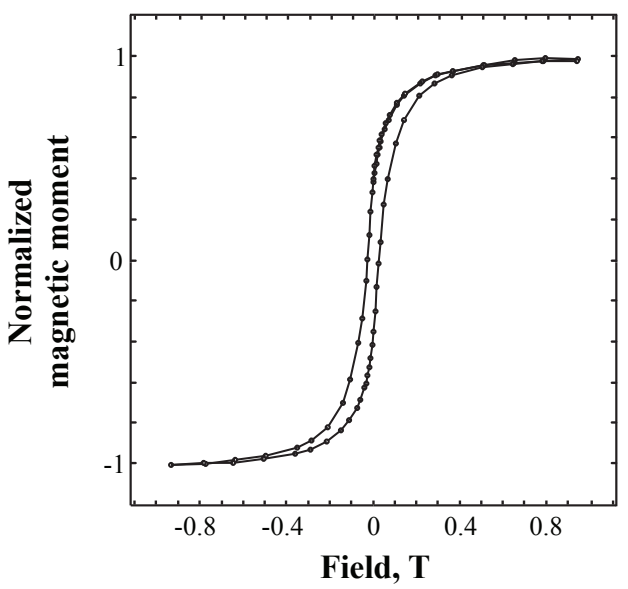

(e) DM02-07

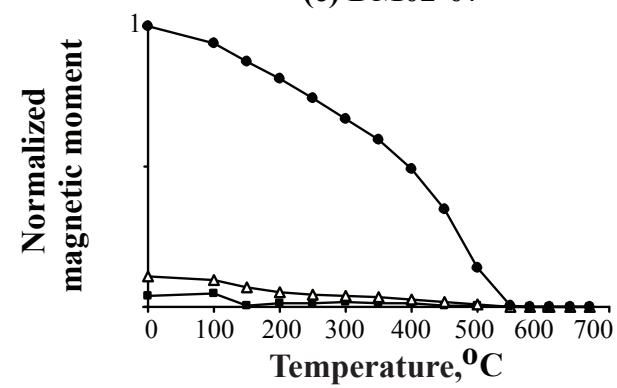

(c) BGA01-05

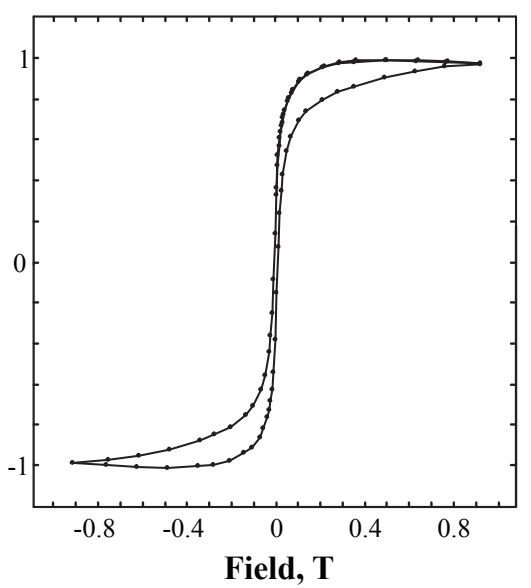

(f) $\mathrm{AS01-05}$

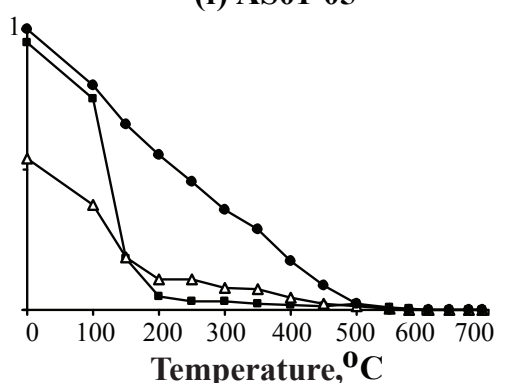

(d) SH01-11

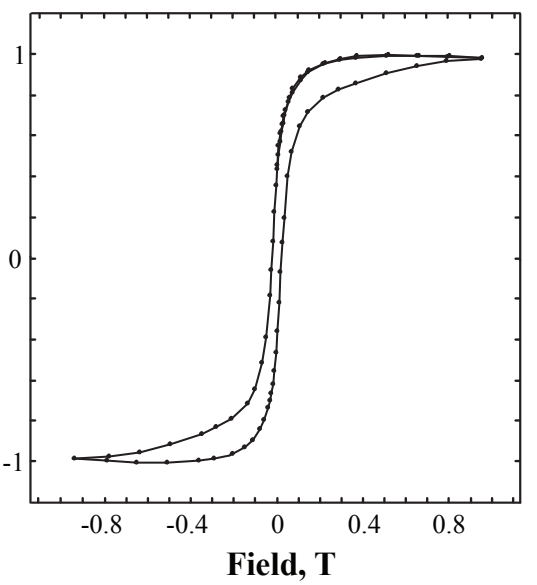

(g) SH01-11

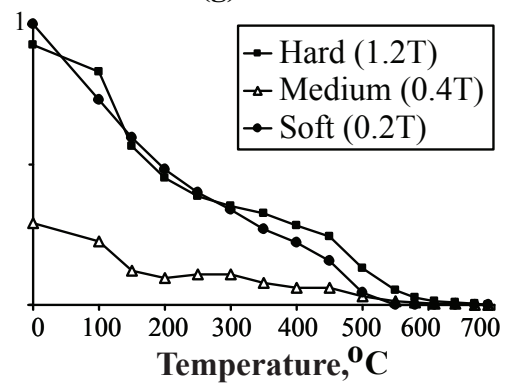


(a) PP01-04c

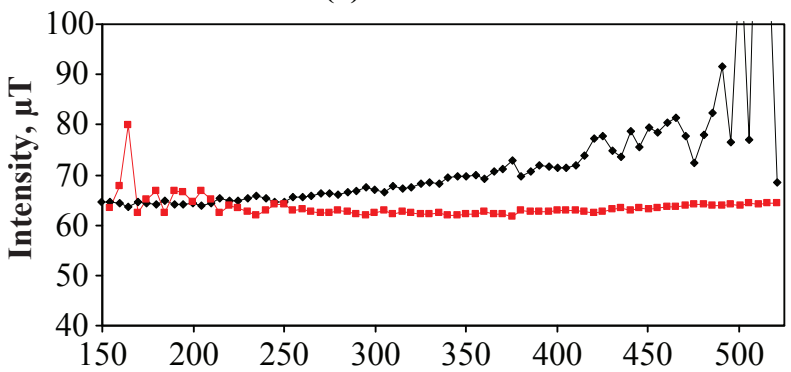

(c) AS01-04a

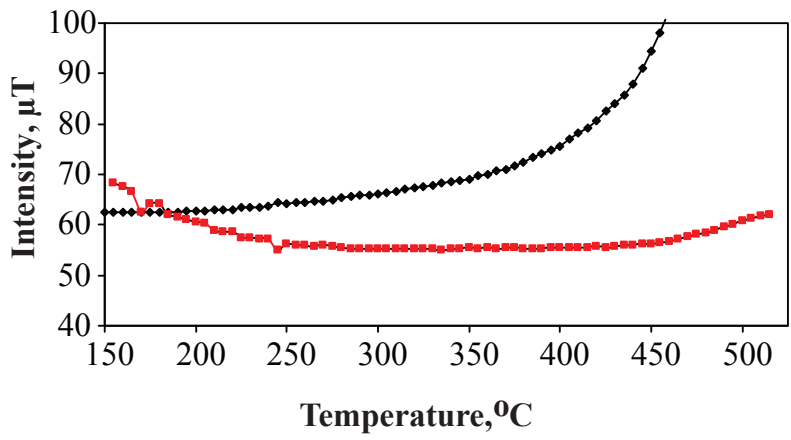

(b) PP01-04a_v2

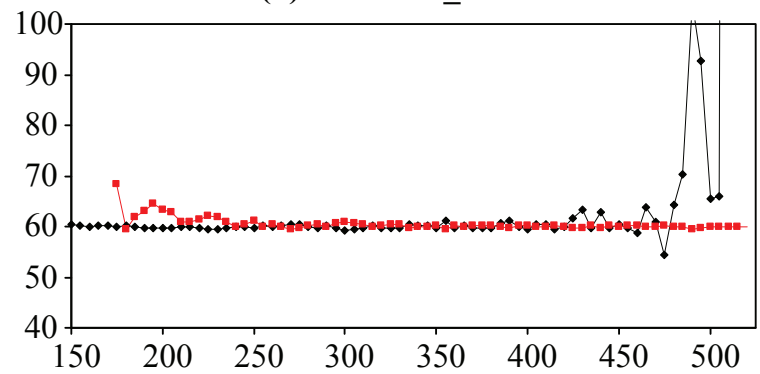

(d) AS01-04f_v2

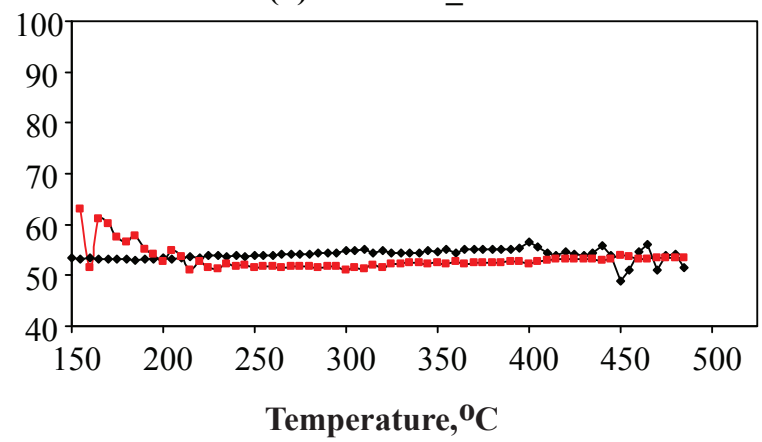

Figure 6 


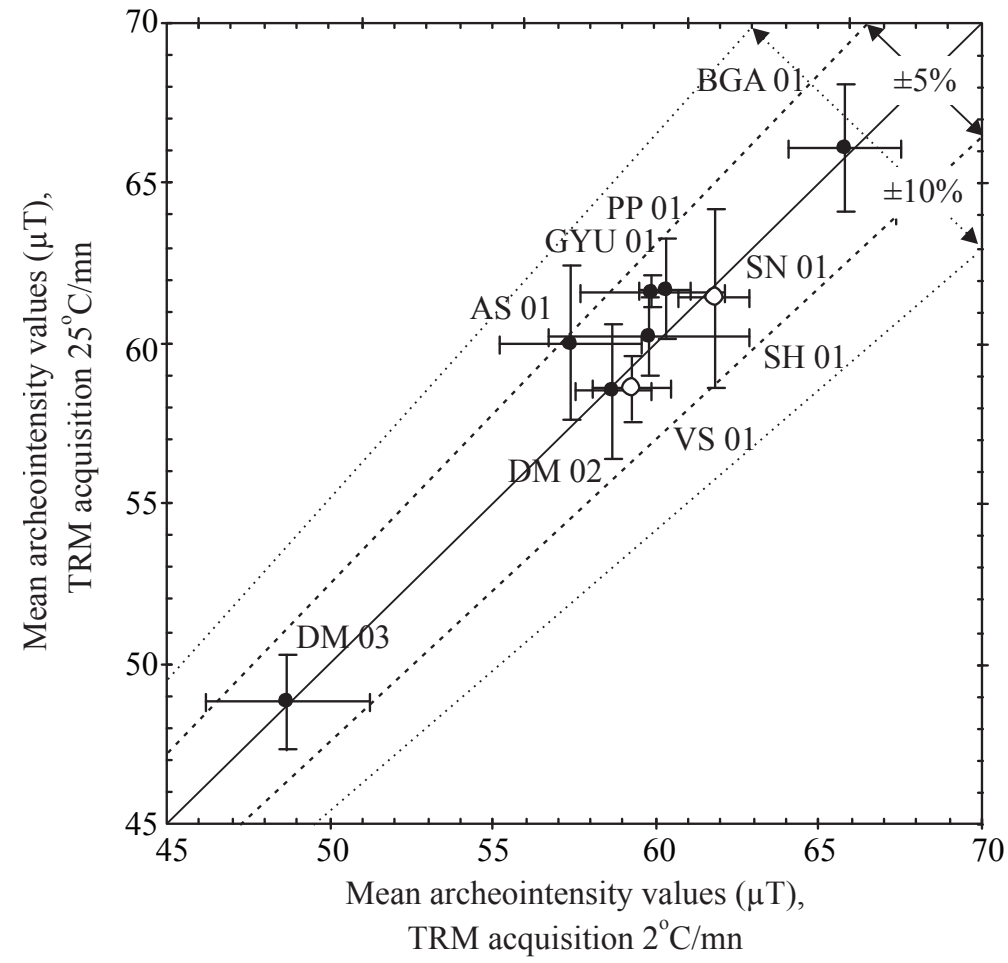

Figure 7 

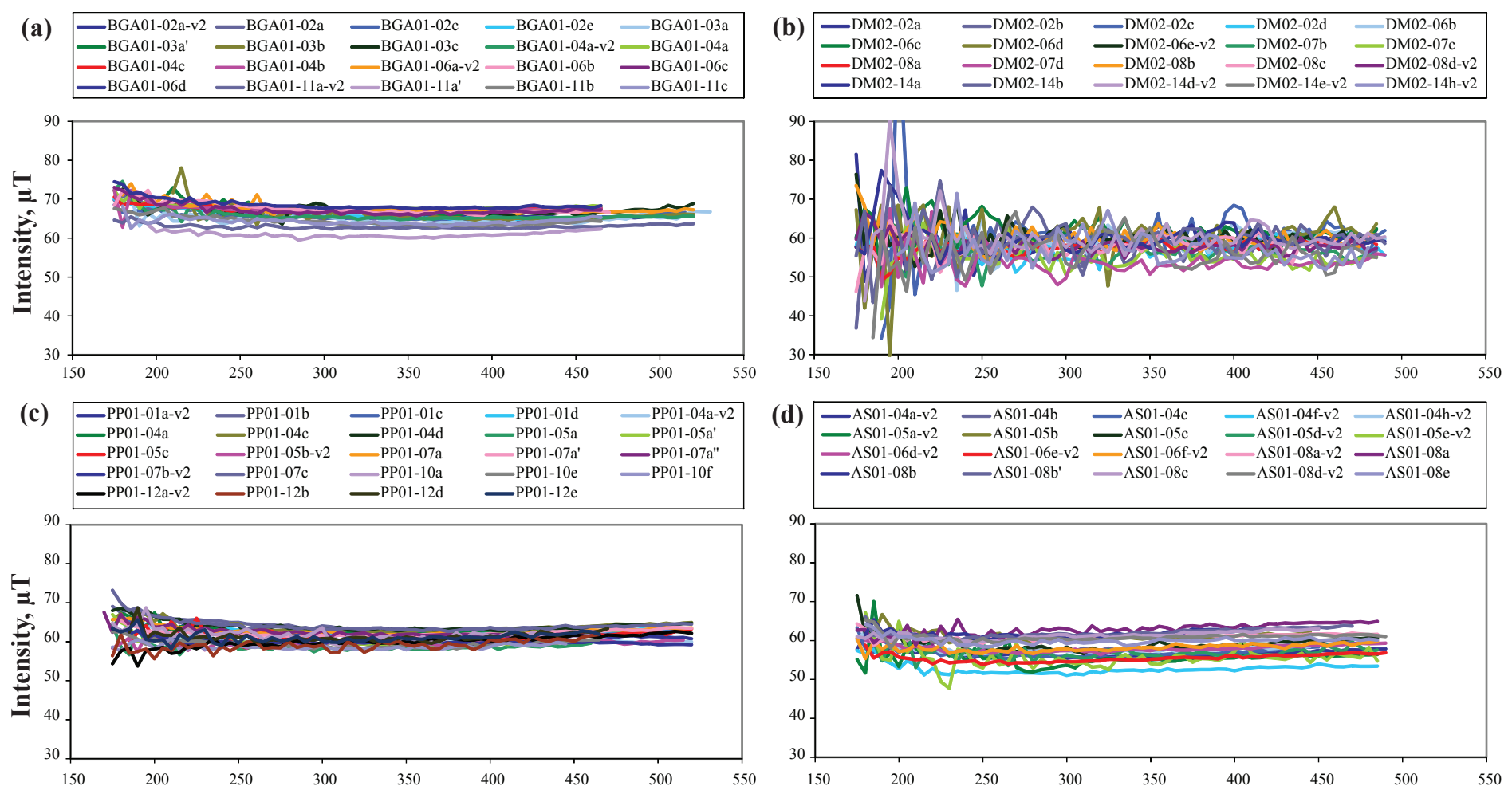

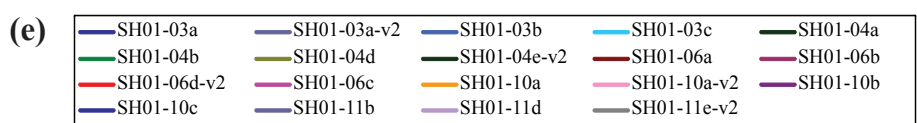
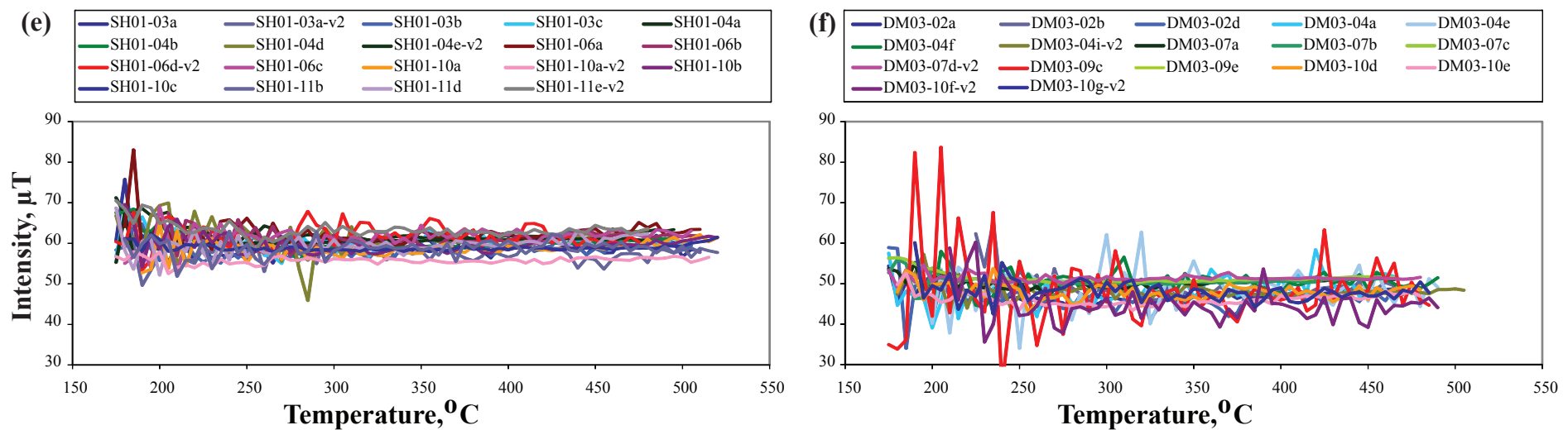
a)

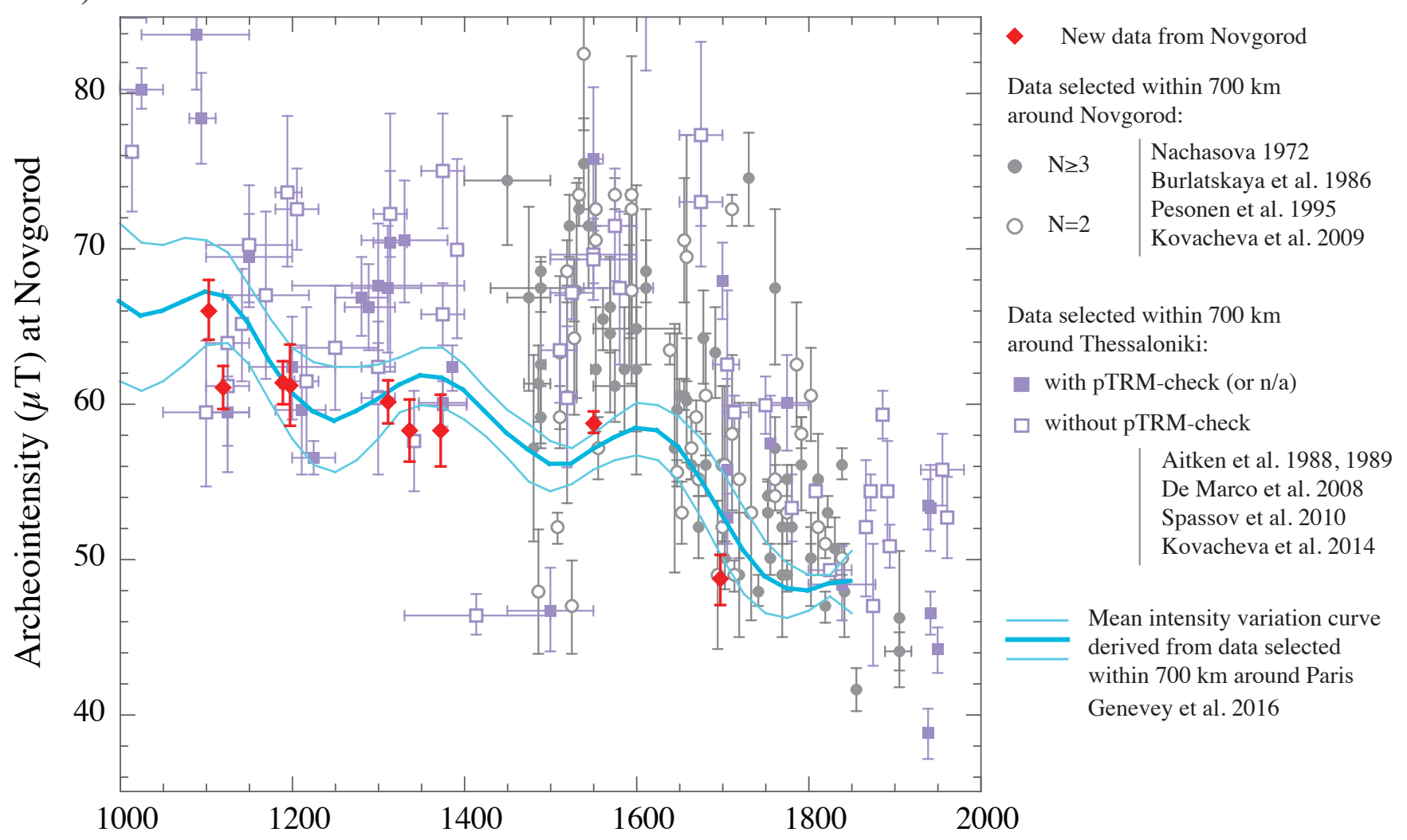

b)

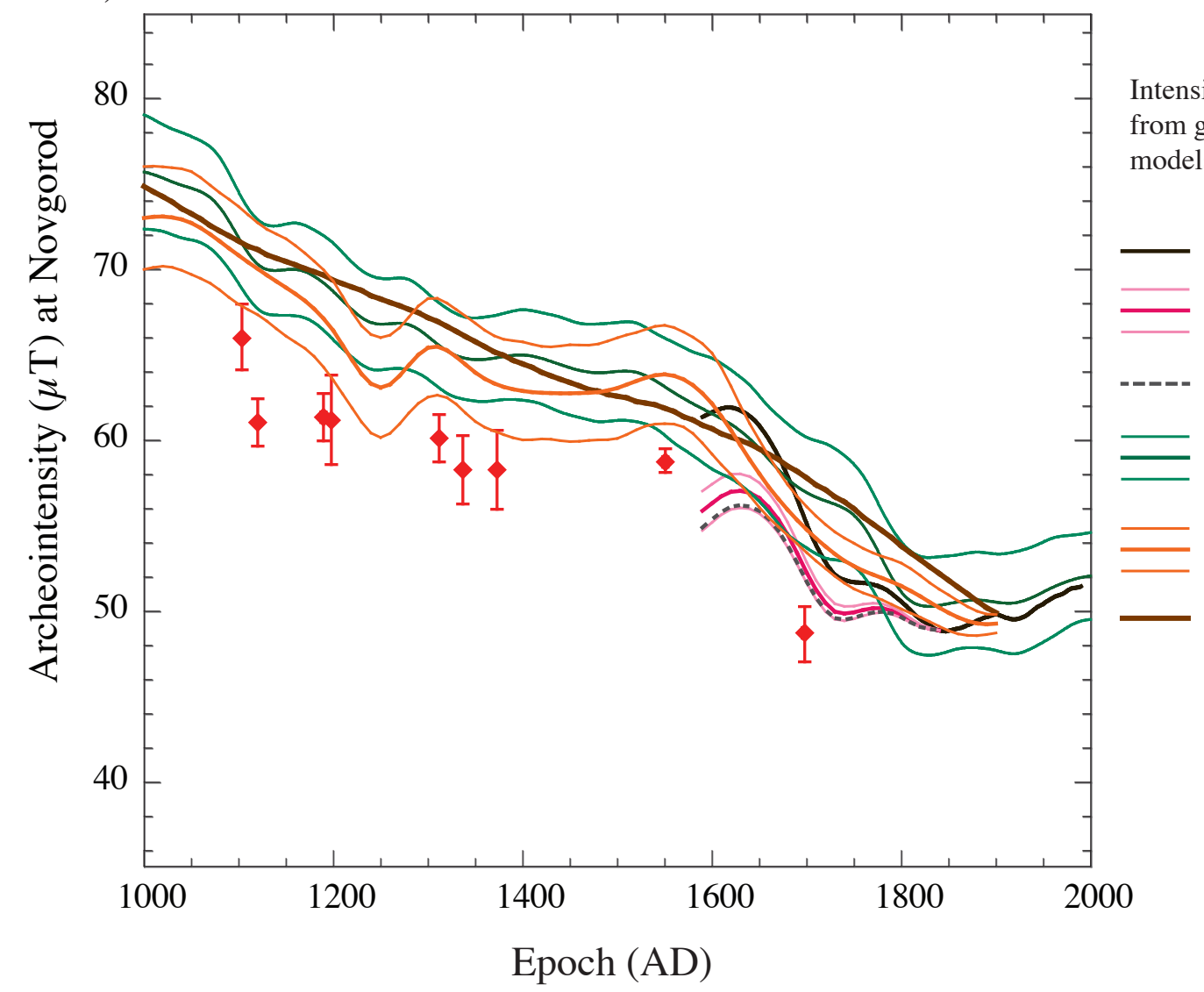

Figure 9 
Table 1

\begin{tabular}{|c|c|c|c|c|c|c|c|}
\hline $\begin{array}{l}\text { Archeomagnetic } \\
\text { group }\end{array}$ & $\begin{array}{l}\text { Lat } \\
\left({ }^{\circ} \mathbf{N}\right)\end{array}$ & $\begin{array}{l}\text { Long } \\
\left({ }^{0} \mathbf{E}\right)\end{array}$ & Site & Age (AD) & $\begin{array}{c}\mathrm{N} \\
\text { fragments }\end{array}$ & $\begin{array}{c}\mathbf{n} \\
\text { specimens }\end{array}$ & $\begin{array}{c}\text { Fmean } \pm \sigma F \\
(\mu T)\end{array}$ \\
\hline BGA01 & 58.49 & 31.30 & Church of the Annunciation in the Gorodishche & 1103 & 5 & 21 & $66.1 \pm 1.9$ \\
\hline GYU01 & 58.49 & 31.28 & Monastery church of St. Georgi & 1119 & 3 & 11 & $61.1 \pm 1.4$ \\
\hline PP01 & 58.51 & 31.26 & $\begin{array}{l}\text { Church to the Holy Apostels Peter and Paul in } \\
\text { Silnishche }\end{array}$ & $1185-1192$ & 6 & 25 & $61.4 \pm 1.4$ \\
\hline SN01 & 58.50 & 31.31 & Transfiguration church on Nereditsa hill & 1198 & 4 & 17 & $61.2 \pm 2.6$ \\
\hline SH01 & 58.48 & 31.30 & $\begin{array}{c}\text { Holy Virgin Protection church of Shilov } \\
\text { Monastery }\end{array}$ & 1310 & 5 & 20 & $60.1 \pm 1.4$ \\
\hline DM02 & 58.56 & 31.30 & $\begin{array}{c}\text { Church of the Holy Resurrection on the } \\
\text { Derevyanitsa river }\end{array}$ & 1335 & 5 & 21 & $58.3 \pm 2.0$ \\
\hline AS01 & 58.50 & 31.33 & Church of St Andrew the Holy Fool on Sitka & 1371 & 4 & 20 & $58.3 \pm 2.3$ \\
\hline VS01 & 58.58 & 31.23 & $\begin{array}{c}\text { Cathedral of Our Lady of Vladimir of Syrkov } \\
\text { Monastery }\end{array}$ & $1548-1554$ & 3 & 13 & $58.8 \pm 0.7$ \\
\hline DM03 & 58.56 & 31.30 & $\begin{array}{c}\text { Church of the Holy Resurrection on the } \\
\text { Derevyanitsa river }\end{array}$ & $1695-1697$ & 5 & 17 & $48.7 \pm 1.6$ \\
\hline
\end{tabular}



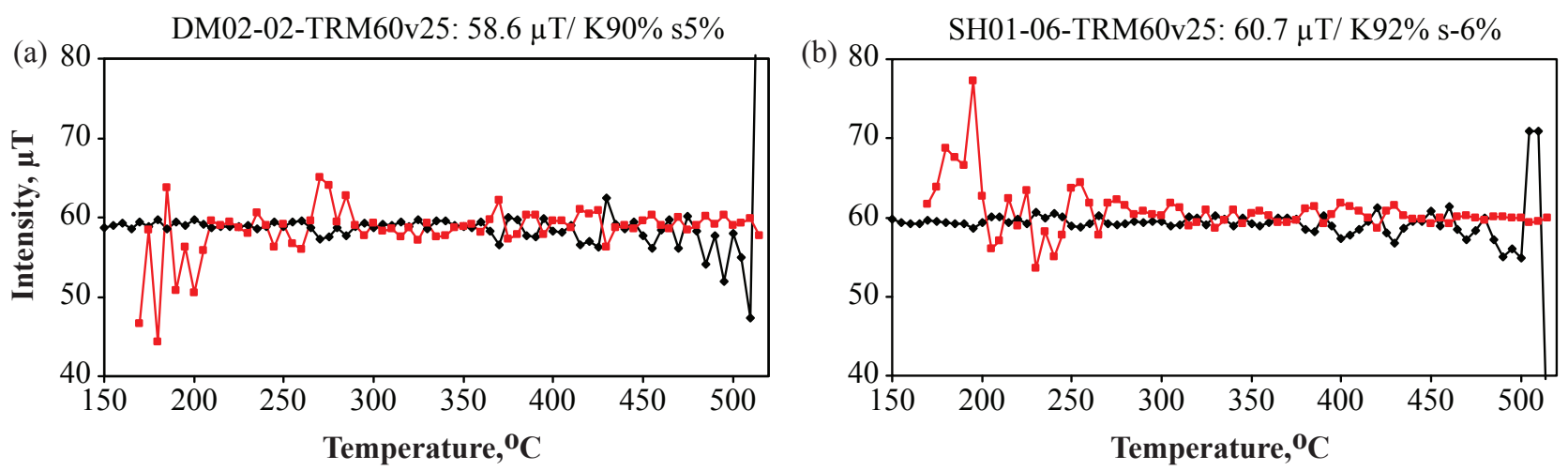
a)

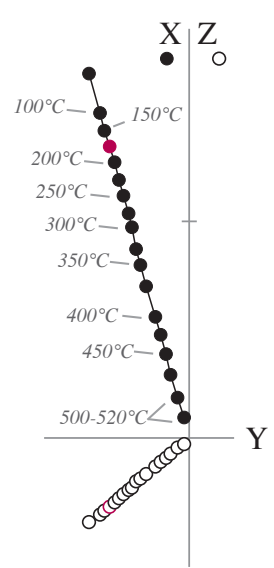

BGA01-03c Scale: $10-1 \mathrm{~A} / \mathrm{m}$

d)

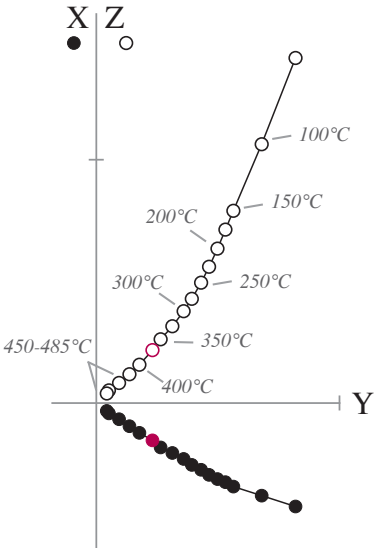

SN01-06b

Scale: $10-1 \mathrm{~A} / \mathrm{m}$

g)

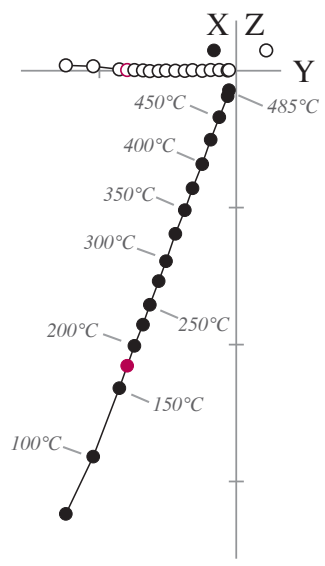

AS01-05c b)

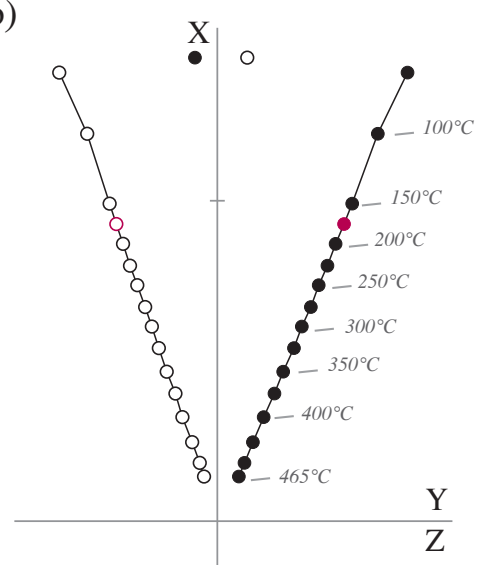

GYU01-02b

e)

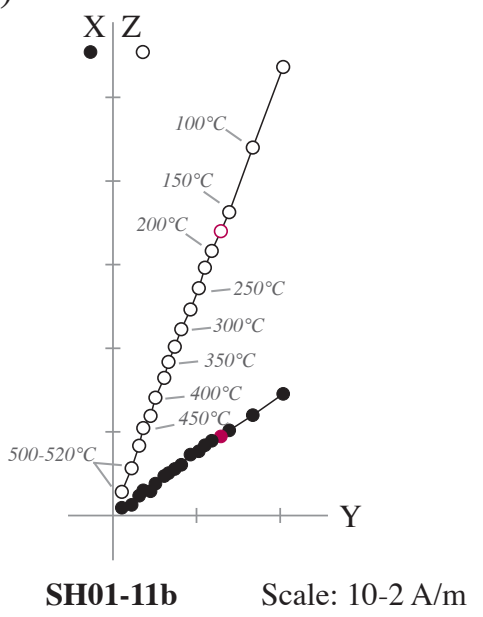

h)

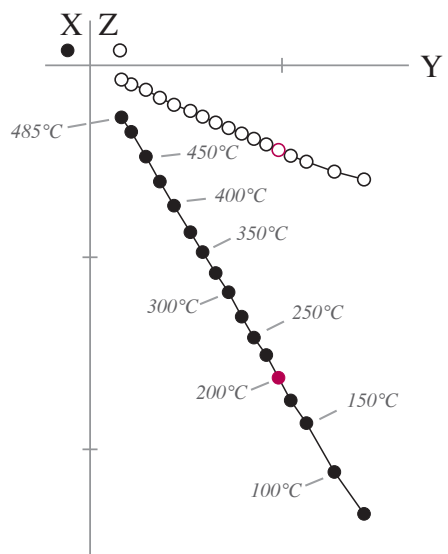

VS01-10a

c)

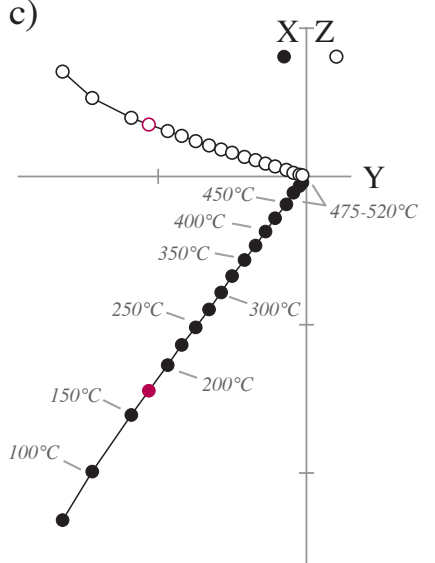

PP01-04c

Scale: $10-1 \mathrm{~A} / \mathrm{m}$

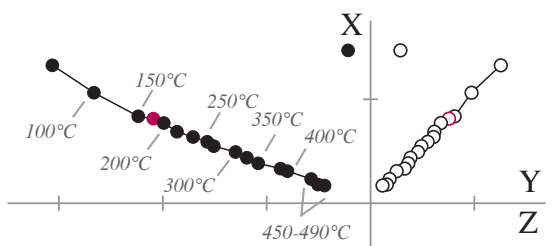

DM02-14c Scale: $10-2 \mathrm{~A} / \mathrm{m}$

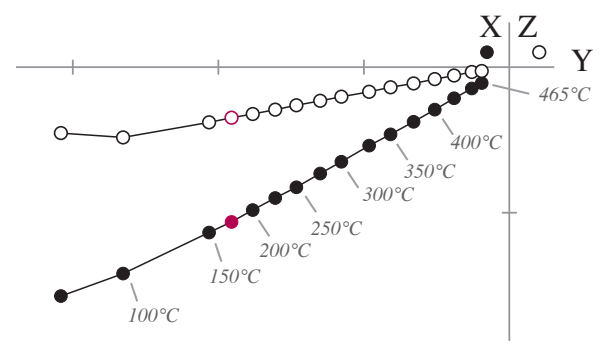

DM03-07a Scale: $10-1 \mathrm{~A} / \mathrm{m}$ 


\begin{tabular}{ccccccccc}
\hline Fragment & Specimen & $\begin{array}{c}\mathrm{T}_{\min }-\mathrm{T}_{\max } \\
\left({ }^{\circ} \mathrm{C}\right)\end{array}$ & $\mathrm{F}_{\mathrm{Lab}}$ & $\begin{array}{c}\text { Cooling } \\
\text { rate, } \\
\left({ }^{\mathrm{o}} \mathrm{C} / \mathrm{mn}\right)\end{array}$ & $\begin{array}{c}\mathrm{T} 1\left(\mathrm{~T} 1^{\prime}\right) \\
(\%)\end{array}$ & $\begin{array}{c}\text { Slope R' } \\
(\%)\end{array}$ & $\begin{array}{c}\mathrm{F}_{\text {Triaxe }} \\
(\mu \mathrm{T})\end{array}$ & $\begin{array}{c}\mathrm{F}_{\text {Triaxe mean }} \\
\text { value per } \\
\text { fragment } \pm \sigma \mathrm{F} \\
(\mu \mathrm{T})\end{array}$ \\
\hline 1 & 3 & 4 & 5 & 6 & 7 & 8 & 9 \\
\hline
\end{tabular}

BGA01, Novgorod, The Church of the Annunciation in the Gorodishche, [1103] AD, (12/12/5)

\begin{tabular}{|c|c|c|c|c|c|c|c|c|}
\hline \multirow[t]{4}{*}{ BGA01-02 } & BGA01-02a & $175-465$ & 65 & 25 & 83 & -8 & 65.8 & \multirow{4}{*}{$66.0 \pm 0.4$} \\
\hline & BGA01-02c & $175-515$ & 65 & 25 & 92 & -2 & 65.5 & \\
\hline & BGA01-02e & $175-465$ & 65 & 25 & 83 & -6 & 66.1 & \\
\hline & BGA01-02a-v2 & $180-520$ & 65 & 2 & 96 & -6 & 66.5 & \\
\hline \multirow[t]{5}{*}{ BGA01-03 } & BGA01-03a & $180-530$ & 65 & 25 & 95 & -2 & 65.2 & \multirow{5}{*}{$66.4 \pm 1.0$} \\
\hline & BGA01-03a' & $205-465$ & 65 & 25 & 65 & -5 & 67.3 & \\
\hline & BGA01-03c & $180-520$ & 65 & 25 & 89 & -2 & 67.1 & \\
\hline & BGA01-03b-v2 & $210-520$ & 65 & 2 & 95 & -5 & 66.0 & \\
\hline & & & 65 & & & & & \\
\hline \multirow[t]{4}{*}{ BGA01-04 } & BGA01-04b & $175-465$ & 65 & 25 & 87 & -2 & 68.0 & \multirow{4}{*}{$67.3 \pm 0.9$} \\
\hline & BGA01-04c & $175-465$ & 65 & 25 & 86 & -2 & 67.5 & \\
\hline & BGA01-04d & $175-465$ & 65 & 25 & 90 & -2 & 67.6 & \\
\hline & BGA01-04a-v2 & $175-520$ & 65 & 2 & 95 & -5 & 65.9 & \\
\hline \multirow[t]{4}{*}{ BGA01-06 } & BGA01-06b & $175-470$ & 65 & 25 & 84 & -6 & 67.6 & \multirow{4}{*}{$67.8 \pm 0.6$} \\
\hline & BGA01-06c & $175-465$ & 65 & 25 & 84 & -5 & 67.3 & \\
\hline & BGA01-06d & $175-465$ & 65 & 25 & 84 & -5 & 68.6 & \\
\hline & BGA01-06a-v2 & $180-520$ & 65 & 2 & 96 & -5 & 67.7 & \\
\hline \multirow[t]{5}{*}{ BGA01-11 } & BGA01-11a & $205-445$ & 65 & 25 & 66 & -4 & 61.8 & \multirow{5}{*}{$62.9 \pm 1.5$} \\
\hline & BGA01-11a' & $195-465$ & 65 & 25 & 79 & 0 & 60.9 & \\
\hline & BGA01-11b & $175-465$ & 65 & 25 & 79 & -5 & 64.4 & \\
\hline & BGA01-11c & $180-465$ & 65 & 25 & 74 & -1 & 64.3 & \\
\hline & BGA01-11a-v2 & $175-520$ & 65 & 2 & 95 & -1 & 63.0 & \\
\hline
\end{tabular}

GYU01, Novgorod, The monastery Church of St. Georgi, [1119] AD, (7/7/3)

$\begin{array}{ccccccccc}\text { GYU01-01 } & \text { GYU01-02b } & 180-465 & 65 & 25 & 78 & -3 & 61.6 & \\ & \text { GYU01-02c } & 215-485 & 65 & 25 & 55 & 8 & 60.5 & 59.7 \pm 1.7 \\ & \text { GYU01-02a-v2 } & 175-485 & 65 & 2 & 89 & 4 & 58.0 & \\ & \text { GYU01-02e-v2 } & 180-465 & 65 & 2 & 69 & 3 & 58.5 & \\ \text { GYU01-04 } & & & & & & & & \\ & \text { GYU01-04a-v2 } & 180-485 & 65 & 2 & 91 & 1 & 62.0 & \\ & \text { GYU01-04d-v2 } & 180-485 & 65 & 2 & 91 & -1 & 62.4 & 62.4 \pm 0.4 \\ & \text { GYU01-04f-v2 } & 175-480 & 60 & 2 & 91 & -2 & 62.7 & \\ \text { GYU01-07 } & & & & & & & \\ & \text { GYU01-07a } & 215-485 & 65 & 25 & 56 & 5 & 61.5 & \\ & \text { GYU01-07b } & 200-485 & 65 & 25 & 51 & 2 & 61.5 & 61.4 \pm 1.7\end{array}$




\begin{tabular}{|c|c|c|c|c|c|c|c|c|}
\hline 1 & 2 & 3 & 4 & 5 & 6 & 7 & 8 & 9 \\
\hline \multicolumn{9}{|c|}{ PP01, Novgorod, The Church to the Holy Apostels Peter and Paul in Silnishche, [1185 - 1192] AD, (12/10/6 } \\
\hline \multirow[t]{4}{*}{ PP01-01 } & PP01-01b & $175-510$ & 60 & 25 & 95 & -5 & 64.3 & \multirow{4}{*}{$62.7 \pm 1.1$} \\
\hline & PP01-01c & $180-510$ & 60 & 25 & 96 & -3 & 62.1 & \\
\hline & PP01-01d & $180-510$ & 60 & 25 & 96 & -1 & 62.6 & \\
\hline & PP01-01a-v2 & $200-520$ & 60 & 2 & 97 & -4 & 61.9 & \\
\hline \multirow[t]{4}{*}{ РP01-04 } & PP01-04a & $175-440$ & 60 & 25 & 80 & -4 & 63.0 & \multirow{4}{*}{$62.8 \pm 1.6$} \\
\hline & PP01-04c & $175-520$ & 60 & 25 & 96 & -1 & 63.7 & \\
\hline & PP01-04d & $175-520$ & 60 & 25 & 96 & -3 & 64.0 & \\
\hline & PP01-04a-v2 & $195-520$ & 60 & 2 & 98 & -3 & 60.4 & \\
\hline \multirow[t]{4}{*}{ PP01-05 } & PP01-05c & $185-520$ & 60 & 25 & 92 & 0 & 61.4 & \multirow{4}{*}{$60.0 \pm 1.1$} \\
\hline & PP01-05a & $175-460$ & 60 & 25 & 76 & -2 & 58.8 & \\
\hline & PP01-05a' & $175-445$ & 60 & 25 & 70 & -5 & 60.1 & \\
\hline & PP01-05b-v2 & $175-515$ & 60 & 2 & 93 & 1 & 59.7 & \\
\hline \multirow[t]{5}{*}{ PP01-07 } & PP01-07a & $175-520$ & 60 & 25 & 97 & -2 & 62.7 & \multirow{5}{*}{$62.3 \pm 1.5$} \\
\hline & PP01-07a' & $180-520$ & 60 & 25 & 97 & 1 & 62.2 & \\
\hline & PP01-07a" & $170-465$ & 60 & 25 & 88 & -6 & 62.6 & \\
\hline & PP01-07c & $175-520$ & 60 & 25 & 97 & -5 & 64.2 & \\
\hline & PP01-07b-v2 & $175-520$ & 60 & 2 & 97 & -3 & 60.0 & \\
\hline \multirow[t]{4}{*}{ PP01-10 } & PP01-10a & $175-460$ & 60 & 25 & 85 & -4 & 61.8 & \multirow{4}{*}{$59.9 \pm 1.3$} \\
\hline & PP01-10e & $175-465$ & 60 & 25 & 84 & -2 & 59.4 & \\
\hline & PP01-10f & $175-445$ & 60 & 25 & 81 & 0 & 58.7 & \\
\hline & PP01-10a-v2 & $170-505$ & 60 & 2 & 91 & -1 & 59.6 & \\
\hline \multirow[t]{4}{*}{ РP01-12 } & PP01-12b & $175-465$ & 60 & 25 & 78 & 5 & 59.1 & \multirow{4}{*}{$60.4 \pm 1.1$} \\
\hline & PP01-12d & $185-465$ & 60 & 25 & 75 & 0 & 61.4 & \\
\hline & PP01-12e & $175-465$ & 60 & 25 & 76 & 1 & 61.2 & \\
\hline & PP01-12a-v2 & $175-520$ & 60 & 2 & 93 & 9 & 60.0 & \\
\hline
\end{tabular}

SN01, Novgorod, The Transfiguration church on Nereditsa hill, [1198] AD, (11/9/4)

$\begin{array}{lcccccccc}\text { SN01-02 } & \text { SN01-02a } & 190-485 & 60 & 25 & 91 & 1 & 61.0 & \\ & \text { SN01-02a' } & 200-465 & 60 & 25 & 79 & -4 & 59.6 & \\ & \text { SN01-02b } & 205-465 & 60 & 25 & 81 & 2 & 61.2 & 60.8 \pm 0.8 \\ & \text { SN01-02c } & 200-465 & 60 & 25 & 82 & -3 & 61.6 & \\ & \text { SN01-02d-v2 } & 195-480 & 60 & 2 & 91 & -3 & 60.7 & \\ \text { SN01-04 } & & & & & & & & \\ & \text { SN01-04a } & 175-485 & 60 & 25 & 91 & -3 & 57.5 & \\ & \text { SN01-04b } & 180-485 & 60 & 25 & 74 & 0 & 55.6 & 57.9 \pm 2.6 \\ & \text { SN01-04c } & 175-480 & 60 & 25 & 90 & -7 & 60.7 & \\ \text { SN01-06 } & & & & & & & & \\ & \text { SN01-06b } & 375-485 & 60 & 25 & 79 & 3 & 62.6 & \\ & \text { SN01-06d } & 350-485 & 60 & 25 & 78 & 3 & 65.9 & 64.2 \pm 1.8\end{array}$




\begin{tabular}{ccccccccc}
\hline 1 & 2 & 3 & 4 & 5 & 6 & 7 & 8 & 9 \\
\hline SN01-09 & SN01-09a & $395-485$ & 60 & 25 & 86 & -1 & 62.4 & \\
& SN01-09b & $395-485$ & 60 & 25 & 87 & 3 & 61.6 & \\
& SN01-09c & $395-485$ & 60 & 25 & 87 & 4 & 63.4 & $62.0 \pm 1.1$ \\
& SN01-09d & $385-485$ & 60 & 25 & 88 & 6 & 62.2 & \\
& SN01-09e & $380-485$ & 60 & 25 & 89 & 4 & 60.3 &
\end{tabular}

SH01, Novgorod, Holy Virgin Protection church of Shilov monastery, [1310] AD, (8/8/5)

\begin{tabular}{|c|c|c|c|c|c|c|c|c|}
\hline \multirow[t]{4}{*}{ SH01-03 } & SH01-03a & $175-510$ & 60 & 25 & 75 & -1 & 59.1 & \multirow{4}{*}{$59.2 \pm 1.1$} \\
\hline & SH01-03b & $175-505$ & 60 & 25 & 73 & 2 & 59.1 & \\
\hline & SH01-03c & $175-505$ & 60 & 25 & 74 & -1 & 60.6 & \\
\hline & SH01-03a-v2 & $180-510$ & 60 & 2 & 74 & -3 & 57.8 & \\
\hline \multirow[t]{4}{*}{ SH01-04 } & SH01-04a & $175-495$ & 60 & 25 & 95 & -6 & 62.6 & \multirow{4}{*}{$61.1 \pm 1.1$} \\
\hline & SH01-04b & $175-495$ & 60 & 25 & 93 & -5 & 60.2 & \\
\hline & SH01-04d & $175-480$ & 60 & 25 & 81 & -1 & 61.2 & \\
\hline & SH01-04e-v2 & $175-480$ & 60 & 2 & 86 & 3 & 60.5 & \\
\hline \multirow[t]{4}{*}{ SH01-06 } & SH01-06a & $180-510$ & 60 & 25 & 77 & -1 & 62.4 & \multirow{4}{*}{$61.8 \pm 0.5$} \\
\hline & SH01-06b & $205-510$ & 60 & 25 & 74 & 0 & 61.3 & \\
\hline & SH01-06c & $180-505$ & 60 & 25 & 75 & 5 & 61.5 & \\
\hline & SH01-06d-v2 & $175-475$ & 60 & 2 & 55 & -1 & 61.8 & \\
\hline \multirow[t]{4}{*}{ SH01-10 } & SH01-10a & $190-520$ & 60 & 25 & 86 & 5 & 58.7 & \multirow{4}{*}{$58.2 \pm 1.7$} \\
\hline & SH01-10b & $180-520$ & 60 & 25 & 94 & -2 & 59.6 & \\
\hline & SH01-10c & $180-520$ & 60 & 25 & 86 & 0 & 58.9 & \\
\hline & SH01-10a-v2 & $175-515$ & 60 & 2 & 92 & 1 & 55.7 & \\
\hline \multirow[t]{4}{*}{ SH01-11 } & SH01-11b & $180-520$ & 60 & 25 & 86 & 1 & 58.8 & \multirow{4}{*}{$60.3 \pm 2.1$} \\
\hline & SH01-11c & $180-520$ & 60 & 25 & 85 & -6 & 59.3 & \\
\hline & SH01-11d & $175-480$ & 60 & 25 & 53 & 4 & 59.6 & \\
\hline & SH01-11e-v2 & $175-480$ & 60 & 2 & 53 & -4 & 63.4 & \\
\hline
\end{tabular}

DM02, Novgorod, Church of the Holy Resurrection by the river Derevyanitsa, [1335]AD, (10/9/5)

\begin{tabular}{|c|c|c|c|c|c|c|c|c|}
\hline \multirow[t]{4}{*}{ DM02-02 } & DM02-02a & $175-485$ & 65 & 25 & 61 & 5 & 58.9 & \multirow{4}{*}{$58.9 \pm 1.2$} \\
\hline & DM02-02b & $175-485$ & 65 & 25 & 70 & 6 & 58.1 & \\
\hline & DM02-02c & $190-490$ & 65 & 25 & 64 & 2 & 60.5 & \\
\hline & DM02-02d & $175-490$ & 65 & 25 & 69 & -1 & 57.9 & \\
\hline \multirow[t]{4}{*}{ DM02-06 } & DM02-06b & $225-490$ & 65 & 25 & 73 & 6 & 59.5 & \multirow{4}{*}{$60.4 \pm 0.9$} \\
\hline & DM02-06c & $175-485$ & 65 & 25 & 72 & -6 & 61.7 & \\
\hline & DM02-06d & $175-485$ & 65 & 25 & 69 & 8 & 60.2 & \\
\hline & DM02-06e-v2 & $175-480$ & 60 & 2 & 64 & -3 & 60.1 & \\
\hline \multirow[t]{3}{*}{ DM02-07 } & DM02-07b & $195-485$ & 65 & 25 & 64 & -1 & 56.2 & \multirow{3}{*}{$55.0 \pm 1.3$} \\
\hline & DM02-07c & $190-485$ & 65 & 25 & 63 & -2 & 55.0 & \\
\hline & DM02-07d & $190-490$ & 65 & 25 & 62 & -3 & 53.7 & \\
\hline \multirow[t]{4}{*}{ DM02-08 } & DM02-08a & $175-485$ & 65 & 25 & 66 & 6 & 57.7 & \multirow{4}{*}{$58.4 \pm 1.1$} \\
\hline & DM02-08b & $175-485$ & 65 & 25 & 66 & -7 & 60.1 & \\
\hline & DM02-08c & $175-485$ & 65 & 25 & 64 & 5 & 57.9 & \\
\hline & DM02-08d-v2 & $175-485$ & 60 & 2 & 65 & -5 & 58.0 & \\
\hline
\end{tabular}




\begin{tabular}{ccccccccc}
\hline 1 & 2 & 3 & 4 & 5 & 6 & 7 & 8 & 9 \\
\hline DM02-14 & DM02-14a & $175-490$ & 65 & 25 & 59 & -5 & 60.2 & \\
& DM02-14b & $175-490$ & 65 & 25 & 70 & 0 & 59.6 & \\
& DM02-14c & $185-490$ & 65 & 25 & 69 & -2 & 59.7 & $58.9 \pm 1.7$ \\
& DM02-14d & $180-490$ & 65 & 2 & 57 & -6 & 60.3 & \\
& DM02-14e & $185-485$ & 60 & 2 & 66 & 1 & 56.4 & \\
& DM02-14h & $200-480$ & 60 & 2 & 64 & -7 & 57.2 &
\end{tabular}

AS01, Novgorod, The church of St Andrew the Holy Fool on Sitka, [1371] AD, (11/6/4)

\begin{tabular}{|c|c|c|c|c|c|c|c|c|}
\hline \multirow[t]{5}{*}{ AS01-04 } & AS01-04b & $175-470$ & 65 & 25 & 78 & 1 & 58.1 & \multirow{5}{*}{$56.4 \pm 2.2$} \\
\hline & AS01-04c & $175-450$ & 65 & 25 & 60 & -1 & 56.9 & \\
\hline & AS01-04a-v2 & $175-490$ & 65 & 2 & 82 & 0 & 56.7 & \\
\hline & AS01-04f-v2 & $175-485$ & 60 & 2 & 91 & -1 & 52.7 & \\
\hline & AS01-04h-v2 & $175-445$ & 60 & 2 & 68 & -2 & 57.8 & \\
\hline \multirow[t]{5}{*}{ AS01-05 } & AS01-05b & $180-445$ & 65 & 25 & 74 & -2 & 61.1 & \multirow{5}{*}{$57.7 \pm 2.4$} \\
\hline & AS01-05c & $175-485$ & 65 & 25 & 90 & -1 & 59.2 & \\
\hline & AS01-05a-v2 & $175-485$ & 65 & 2 & 89 & -2 & 55.7 & \\
\hline & AS01-05d-v2 & $180-485$ & 60 & 2 & 82 & -2 & 57.0 & \\
\hline & AS01-05e-v2 & $180-485$ & 60 & 2 & 76 & -2 & 55.7 & \\
\hline \multirow[t]{3}{*}{ AS01-06 } & AS01-06d-v2 & $180-490$ & 60 & 2 & 86 & 2 & 58.0 & \multirow{3}{*}{$57.2 \pm 1.6$} \\
\hline & AS01-06e-v2 & $180-490$ & 60 & 2 & 90 & 3 & 55.4 & \\
\hline & AS01-06f-v2 & $175-485$ & 60 & 2 & 89 & 3 & 58.2 & \\
\hline \multirow[t]{8}{*}{ AS01-08 } & AS01-08a & $175-485$ & 65 & 25 & 72 & 7 & 62.9 & \multirow{8}{*}{$61.6 \pm 1.1$} \\
\hline & AS01-08b & $180-450$ & 65 & 25 & 84 & 3 & 61.9 & \\
\hline & AS01-08b' & $180-470$ & 65 & 25 & 81 & 4 & 62.0 & \\
\hline & AS01-08b" & $175-485$ & 65 & 25 & 88 & 4 & 63.3 & \\
\hline & AS01-08c & $175-450$ & 65 & 25 & 80 & 5 & 61.3 & \\
\hline & AS01-08d-v2 & $180-490$ & 60 & 2 & 90 & 1 & 60.8 & \\
\hline & AS01-08e-v2 & $180-485$ & 60 & 2 & 88 & -1 & 60.0 & \\
\hline & AS01-08a-v2 & $175-485$ & 65 & 2 & 84 & 2 & 60.9 & \\
\hline
\end{tabular}

VS01, Novgorod, Cathedral of Our Lady of Vladimir in Syrkov Monastery, [1548 - 1554] AD, (11/5/3)

\begin{tabular}{ccccccccc} 
VS01-02 & VS01-02a & $200-465$ & 50 & 25 & 58 & -9 & 58.5 & \\
& VS01-02b & $180-465$ & 50 & 25 & 66 & 6 & 55.4 & $58.5 \pm 2.2$ \\
& VS01-02d & $195-465$ & 60 & 25 & 58 & -8 & 59.5 & \\
& VS01-02a-v2 & $175-510$ & 50 & 2 & 90 & -8 & 60.5 & \\
VS01-04 & & & & & & & & \\
& VS01-04b & $175-485$ & 50 & 25 & 82 & 0 & 61.0 & \\
& VS01-04c & $175-465$ & 60 & 25 & 66 & 3 & 57.0 & $58.3 \pm 1.6$ \\
& VS01-04d & $175-485$ & 60 & 25 & 62 & -5 & 58.5 & \\
& VS01-04f & $175-465$ & 60 & 25 & 68 & 1 & 57.0 & \\
\multirow{5}{*}{ VS01-10 } & VS01-04a-v2 & $175-510$ & 50 & 2 & 86 & -6 & 58.1 & \\
& VS01-10a & $195-485$ & 50 & 25 & 77 & -3 & 59.5 & \\
& VS01-10b & $200-465$ & 60 & 25 & 63 & -5 & 59.6 & \\
& VS01-10c & $180-465$ & 60 & 25 & 70 & -8 & 60.0 & $59.7 \pm 0.2$
\end{tabular}




\begin{tabular}{|c|c|c|c|c|c|c|c|c|}
\hline 1 & 2 & 3 & 4 & 5 & 6 & 7 & 8 & 9 \\
\hline \multicolumn{9}{|c|}{ DM03, Novgorod, Church of the Holy Resurrection by the river Derevyanitsa, [1695-1697] AD, (11/8/5) } \\
\hline \multirow[t]{3}{*}{ DM03-02 } & DM03-02a & $175-465$ & 50 & 25 & 70 & -2 & 47.2 & \multirow{3}{*}{$47.6 \pm 1.3$} \\
\hline & DM03-02b & $225-465$ & 50 & 25 & 62 & -9 & 49.1 & \\
\hline & DM03-02d & $175-470$ & 50 & 25 & 61 & -4 & 46.5 & \\
\hline \multirow[t]{4}{*}{ DM03-04 } & DM03-04a & $175-465$ & 50 & 25 & 60 & 10 & 48.6 & \multirow{4}{*}{$49.1 \pm 1.0$} \\
\hline & DM03-04e & $195-490$ & 50 & 25 & 57 & 2 & 49.1 & \\
\hline & DM03-04f & $190-490$ & 50 & 25 & 55 & -1 & 50.5 & \\
\hline & DM03-04i-v2 & $180-505$ & 50 & 2 & 51 & -4 & 48.2 & \\
\hline \multirow[t]{4}{*}{ DM03-07 } & DM03-07a & $175-465$ & 50 & 25 & 86 & 1 & 50.2 & \multirow{4}{*}{$50.9 \pm 0.6$} \\
\hline & DM03-07b & $175-465$ & 50 & 25 & 84 & -1 & 50.6 & \\
\hline & DM03-07c & $175-465$ & 50 & 25 & 84 & -4 & 51.4 & \\
\hline & DM03-07d & $175-480$ & 50 & 2 & 90 & -1 & 51.4 & \\
\hline \multirow[t]{2}{*}{ DM03-09 } & DM03-09c & $175-485$ & 50 & 25 & 53 & -3 & 48.2 & \multirow{2}{*}{$49.2 \pm 1.0$} \\
\hline & DM03-09e & $175-480$ & 50 & 25 & 56 & -3 & 50.1 & \\
\hline \multirow[t]{4}{*}{ DM03-10 } & DM03-10d & $180-480$ & 50 & 25 & 53 & -2 & 47.9 & \multirow{4}{*}{$46.7 \pm 1.6$} \\
\hline & DM03-10e & $180-480$ & 50 & 25 & 56 & 0 & 46.1 & \\
\hline & DM03-10f-v2 & $210-490$ & 50 & 2 & 54 & -9 & 44.7 & \\
\hline & DM03-10g-v2 & $190-485$ & 50 & 2 & 60 & -7 & 48.2 & \\
\hline
\end{tabular}

